\title{
The Stone Tidal Fish Weirs of the Molène Archipelago, Iroise Sea, Brittany, Western France: a long-term tradition with early megalithic origins
}

\section{Henri Gandois}

UMR Trajectoires, Université de Paris I Panthéon Sorbonne, Paris, France, research associate at the UMR CReAAH, Université de Rennes 1, Rennes, France, henri.gandois@gmail.com

\section{Pierre Stéphan}

CNRS, UMR LETG, Université de Bretagne Occidentale, Institut Universitaire Européen de la Mer, 29280 Plouzané, France. LTSER France, Zone Atelier 'Brest-Iroise', Pierre.stephan@univ-brest.fr

\section{David Cuisnier}

Ferme insulaire de Kemenez, île de Kemenez,Le Conquet, France,dcuisnier@free.fr

Olivia Hulot

DRASSM, Ministère de la Culture et de la Communication, Marseille,France,olivia.hulot@culture.gouv.fr

Axel Ehrhold

IFREMER, Géosciences Marines, Centre, de Brest, BP70, CS10070, 29280 Plouzané, France, Axel.Ehrhold@ifremer.fr

Marine Paul

CNRS, UMR LETG, Université de Bretagne Occidentale, Institut Universitaire Européen de la Mer, 29280 Plouzané, France, Marine.paul@univ-brest.fr

\section{Nicolas Le Dantec}

CEREMA, UMR 6538 Géosciences Océan, Université de Bretagne Occidentale, Institut Universitaire Européen de la Mer, 29280 Plouzané, France

\section{Marcaurelio Franzetti}

CNRS, UMR 6538 Géosciences Océan, Université de Bretagne Occidentale, Institut Universitaire Européen de la Mer, 29280 Plouzané, France

This reports on a project that combined evidence gleaned from aerial photographs, place-names, interviews, topography, LIDAR data, and sonar bathymetry to locate stone tidal fish weirs in the Molène Archipelago. The results were verified by diver and pedestrian visual surveys. Models of Holocene sea-level change allowed a group of possibly Late Mesolithic-Early Neolithic weirs to be recognized, with a second group broadly dated to the later Neolithic-Early Bronze Age. The construction of these 
long megalithic structures is compared to the funerary monuments for which the Molène Archipelago is well known, in terms of technique, cost, and societal organization.

(C) 2017 The Authors

Key words: Tidal weirs, fish traps, Molène Archipelago, megalithic constructions, sea-level change, Mesolithic, Neolithic.

$\mathrm{T}$ he exploitation of marine resources - shellfish, fish, seaweed, and so on - characterizes human communities living along the coasts. In regions with significant tidal range, people have used the daily fluctuations of sea level to trap fish from fixed structures installed on the foreshore. These structures, named barrage de pêcherie or écluses à poissons in French, tidal fish weirs, fish traps or standing fisheries in English, are either made of rows of wooden stakes and wattle, or dry stone walls, frequently erected between two rocky spurs (Daire and Langouët, 2010: 10-11). Stone fish weirs are known all over the world, from Australia to Alaska, and from Polynesia and Japan to Europe (Connaway, 2007; Daire and Langouët, 2008, 2010; Iwabuchi, 2014). Along the coast of north-western Europe, a high density of tidal weirs has been observed (Daire and Langouët, 2008, 2010). These structures show a great diversity in morpho-sedimentary contexts, in the construction materials used, and in general morphology. Wooden traps have been thoroughly studied, partly as a result of their organic materials allowing precise dating, but little work has been done on the stone structures because of the difficulties of dating them and thus establishing links with adjacent archaeological remains.
Located at the extreme west of the French Atlantic coast, in the Iroise Sea, Brittany, the nine islands forming the Molène Archipelago (Fig. 1) represent the visible part of a vast shallow-water rocky plateau connected to the continent during the Last Glacial Maximum, some 20,000 years ago. The upper part of the continental shelf was subject to long-term, gradual marine inundation and erosional processes due to the Holocene sea-level rise. The Molène plateau first separated from the continent and formed a single large island, which gradually fragmented into a multitude of smaller islands and islets (Stéphan et al., 2013: 647648).

Over the past 10 years, an extensive programme of archaeological research has been conducted on these islands, coupled with the construction of a model of Holocene palaeogeographic changes (Pailler et al., 2014), which highlights significant coastal variations over the past $8000-7000$ years. An exceptional concentration of archaeological remains has provided a detailed overview of the island communities whose subsistence was based on intensive exploitation of marine resources in an environment characterized by a great biodiversity. Issues surrounding strategies

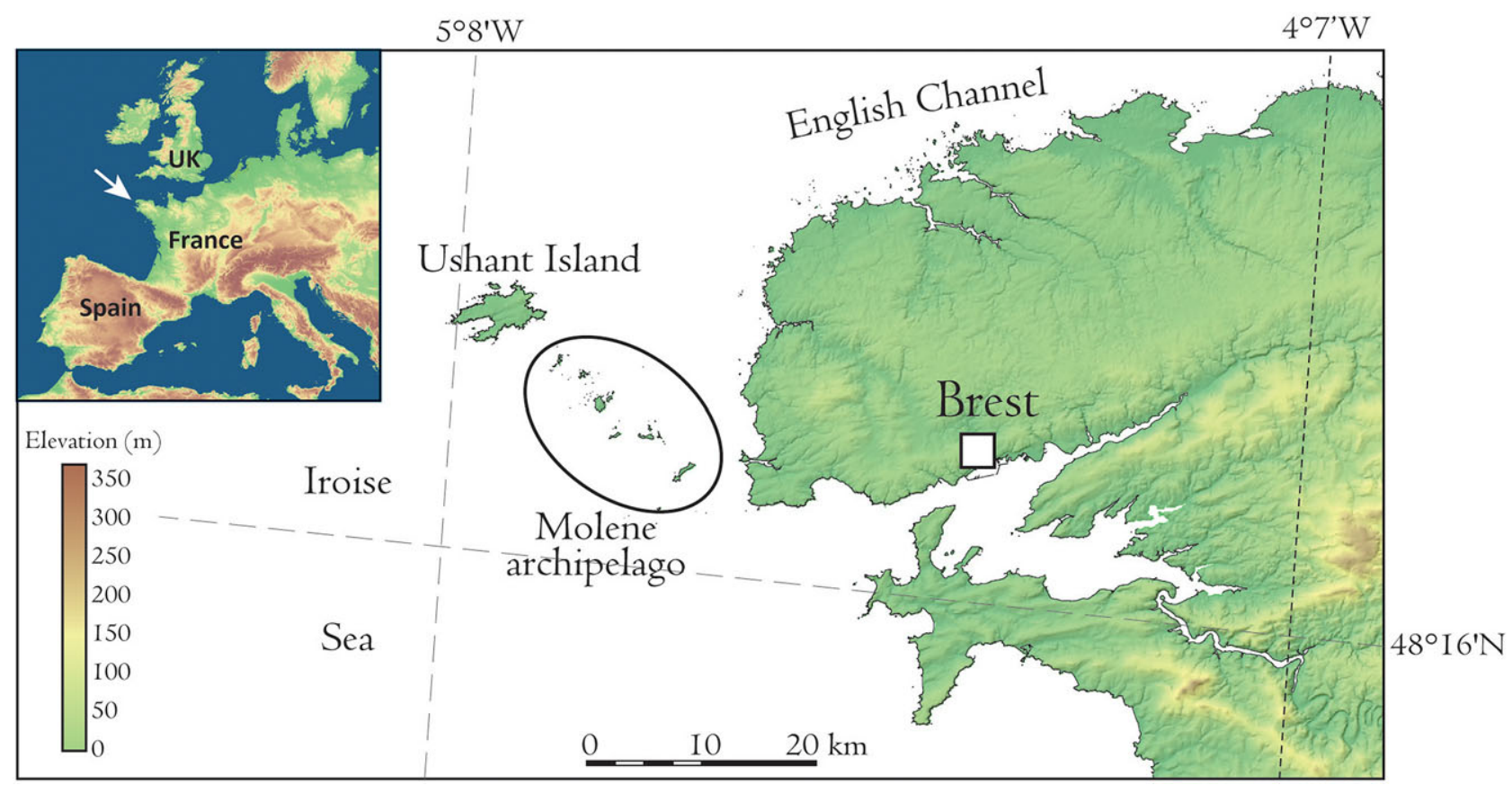

Figure 1. Location map of the study area, west of Brittany, France (CAD: P. Stéphan). 
developed by the past insular communities in response to the evolution of: i) coastal environments; ii) climate; and iii) natural resources is at the heart of the discussions initiated about these islands (Stéphan et al., 2013; Pailler et al., 2014). The several shell middens, funerary monuments and domestic sites excavated have delivered a large quantity of skeletal remains of ichthyofauna (Dréano et al., 2013; Pailler et al., 2014; Gandois et al., 2015a, 2015b, 2017a, 2017b). Almost 10,000 fish skeletal remains were identified. This work represents a reference for the Late Prehistory of the French Atlantic coast. The abundance of fish remains and the types of species found in the shell middens raise many questions about the mid Neolithic-Bronze Age groups' fishing techniques and trapping strategies. No archaeological surveys had been undertaken of the intertidal and subtidal zones of the Molène Archipelago until an extensive project was initiated in 2009 to research remains such as stone tidal weirs (Gandois et al., 2011, 2015a). The purpose of this study is to produce the first inventory of confirmed fishing structures discovered on the foreshore, from underwater observations, and from a preliminary analysis of recent bathymetric surveys. The results are discussed in the context of the known terrestrial remains in order to give the most complete image of the fishing techniques and resources used by insular protohistoric communities.

\section{Geographical setting}

The Molène Archipelago consists of nine main islands (Bannec, Balanec, Molène, Trielen, Ile aux Chrétiens, Kemenez, Litiri, Morgol, and Béniguet) and nine islets connected to the islands during low tide levels (Fig. 2A). Except for some scattered rocks, the elevation of these islands is limited to few metres above the highest water level, which reaches $4.12 \mathrm{~m}$ NGF (French Ordnance Datum) at high spring tides. Molène Island is the highest with a peak of $26 \mathrm{~m} \mathrm{NGF}$ at the centre, while Béniguet has an altitude of $16 \mathrm{~m} \mathrm{NGF}$ in the south. These islands represent the emerged part of a large shallow-water plateau (Molène plateau) bordered by steep submarine slopes of structural origin, with a drop of 20-50m depth (Le Gall et al., 2014). The southeastern part of the Molène plateau is connected to the continent by a narrow shelf of $-11 \mathrm{~m}$ depth. Offshore, a $60 \mathrm{~m}$-deep rift (Fromveur Passage) separates the Molène plateau from Ushant Island. In detail, the morphology of the plateau is characterized by several elongated depressions, caused by strips of softer rock or fractures (Le Gall et al., 2014) that channel tidal currents. In this area, the maximal tidal range is up to $7.9 \mathrm{~m}$, generating strong flood and ebb currents reaching up to $2.5 \mathrm{~m} / \mathrm{s}$ in the Four Channel and $4 \mathrm{~m} / \mathrm{s}$ in the Fromveur Passage at spring tides.

In the Molène Archipelago, the coastline is particularly exposed to erosion by storm waves (Fig. 2B-C). The directional wave spectrum shows that waves are predominantly westerly to north-westerly $\left(270-310^{\circ}\right)$. These waves are the most energetic and represent roughly $60 \%$ of the annual regime (Fichaut and Suanez, 2011). As recorded in recent years by topo-morphological surveys, the most violent storms have caused significant coastal erosion (Suanez et al., 2009, 2011; Blaise et al., 2015). After each episode of shoreline retreat, many archaeological sites (a Bronze Age stone cist, Early Bronze Age necropolis, Middle Neolithic I long barrow and settlement, Neolithic and Bronze Age shell middens, and so on) were uncovered (Gandois et al., 2013b, 2015a, 2015b, 2017a, 2017b).

\section{Relative sea-level history}

The Molène plateau was connected to the continent during the low sea-level stand of the Last Glacial Maximum. During the Holocene period, this coastal area has recorded major palaeogeographic changes related to the post glacial sea-level rise leading to the drowning of a large part of the continental shelf, the formation of islands and a gradual reduction of their land surface (Pailler et al., 2014). In the western part of Brittany, the Holocene RSL rise has recently been studied in detail (Stéphan, 2011; Goslin et al., 2013; Stéphan and Laforge, 2013; Stéphan and Goslin, 2014; Goslin et al., 2015; Stéphan et al., 2015). These studies, which provide 35 new dates for the relative sealevel record, considerably improve the precision of the regional RSL history of the past 8000 years, with a mean positioning uncertainty of around $\pm 0.60 \mathrm{~m}$. This new dataset shows an overall continuous $6.5 \mathrm{~m}$ RSL rise since $5000 \mathrm{cal}$. BC. Following an initial rapid rise between 6000 and 4000 cal. $\mathrm{BC}$ from $c .8 \mathrm{~m}$ to $5 \mathrm{~m}$ below present-day level, there is a marked slowdown in the RSL rise around 4000 cal. BC after which the rate of RSL rise progressively decreases towards present-day values (Goslin et al., 2015).

From these data, Pailler et al. (2014) proposed a model of palaeogeographic changes by simulating the relative rise of sea level on the topo-bathymetric data available. This approach is approximate but likely reliable because there is little sedimentation in the subtidal area. The results of this simulation indicate a great reduction in terrestrial and foreshores areas and a gradual fragmentation of the island territories from the Neolithic to the present-day (Fig. 3). During the past 7000 years, the surface of the archipelago has been reduced from $45 \mathrm{~km}^{2}$ in the Early Neolithic period to around $10 \mathrm{~km}^{2}$ today. The loss of foreshore areas was constant during this period, estimated at $5000 \mathrm{~m}^{2}$ per year, leading to a large reduction of the surface areas available for the collection of the shellfish and the foreshore fishing practices in the surrounding zones of the islands.

\section{Archaeological background}

Research over the past 15 years has highlighted the great density of archaeological remains on the Molène 


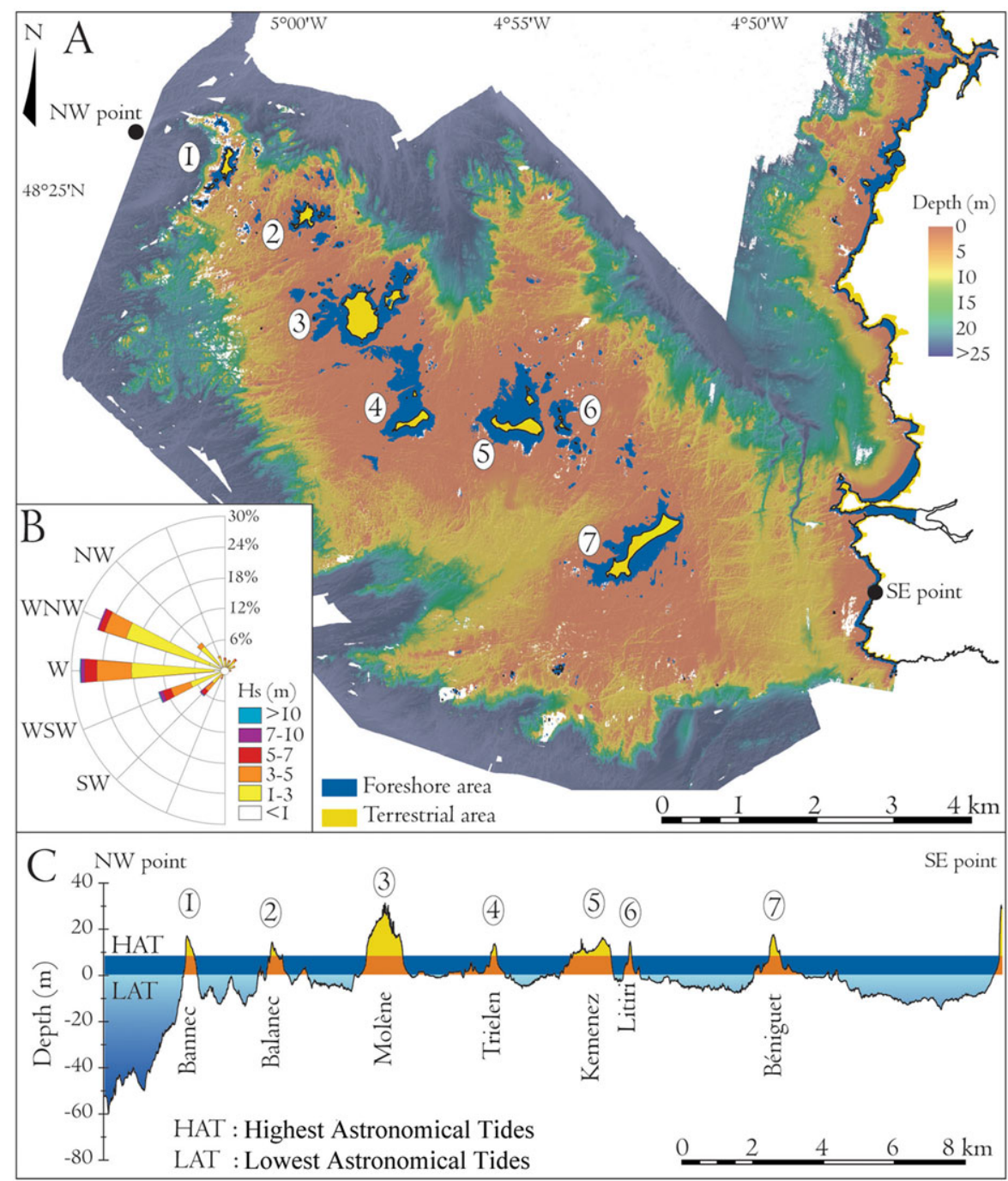

Figure 2. A) Topo-bathymetric map of the Molène Archipelago; B) wave rose from wave data measurements obtained in the south of the Molène Archipelago (Les Pierre Noires buoy); $C$ ) topo-bathymetric profile of the Molène Archipelago from the NW point to the SE point. Numbers correspond to the seven biggest islands of the archipelago.

Archipelago. From 2003 to 2010, a programme of excavations was carried out on an oval-shaped building located on Molène Island, occupied from the Late Neolithic to the Early Bronze Age. In parallel to this work, several surveys and sampling sorties were carried out more specifically on the archipelago's shell middens as within these deposits organic remains are generally very well preserved. The botanic and faunal remains obtained from the archipelago's different archaeological sites constitute primary environmental indicators. An overview of the vegetation was recently obtained by studying an almost continuous sequence of more than 1000 charcoal fragments dated from the Middle Neolithic to the Late Bronze Age (Marcoux in Gandois et al., 2017b: 53-62). During this period, the relic wooded areas composed of light oak forests were gradually reduced as a result of human actions.
Likewise, a study of several hundred burnt seeds allowed a detailed look on the different crop species cultivated on the islands (Berrio in Gandois et al., 2015a: 92-96). Agricultural practices were based on cereal farming attested from the beginning of the Late Neolithic. During the Early Bronze Age, cultivated plants were composed of cereals (hulled and hulless barley, emmer and wheat) and pulses (fava bean and pea). A crop weed, the wild radish, also grew on the islands. Wild nut and fruit trees (hazel, common hawthorn and common dogwood) were also used. Strong cultural links were maintained between the insular and continental populations, as highlighted by the studies of stone and ceramic industries (Pailler et al., 2009, 2014). The abundance of faunal remains, whether marine (fish, mammals, molluscs, crustaceans, and echinoderms) or terrestrial (mammals and birds), 


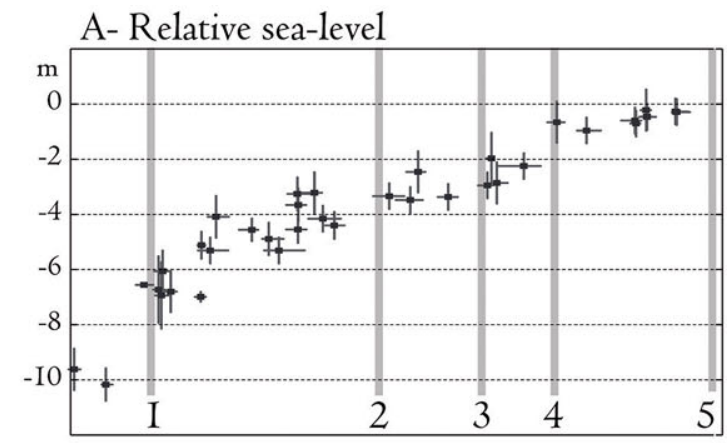

B- Terrestrial area

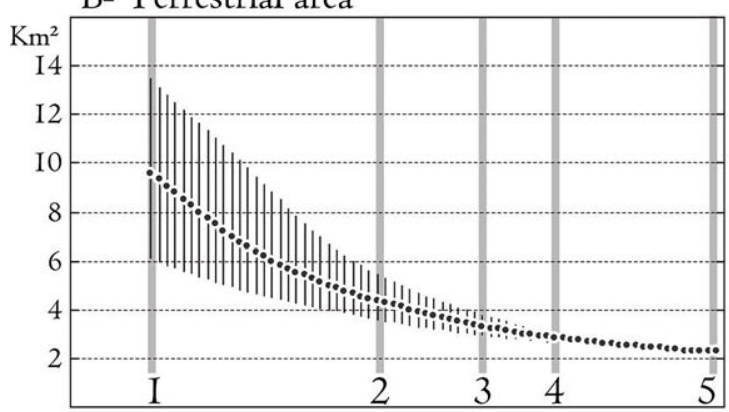

C- Foreshore area

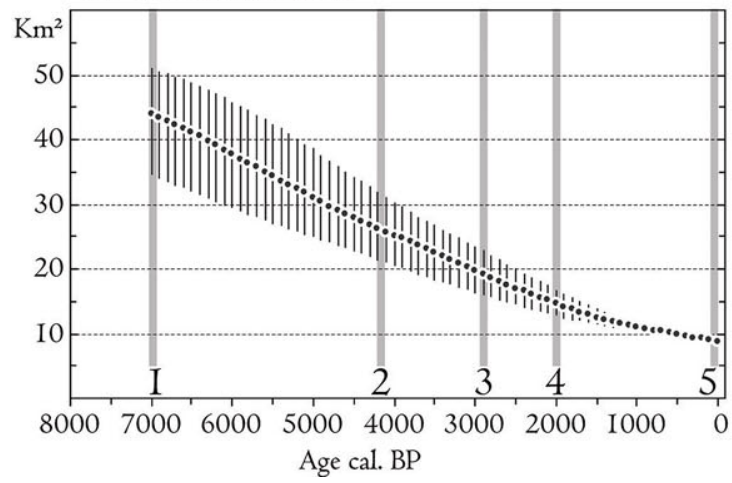

D - Sequence of paleogeographic changes

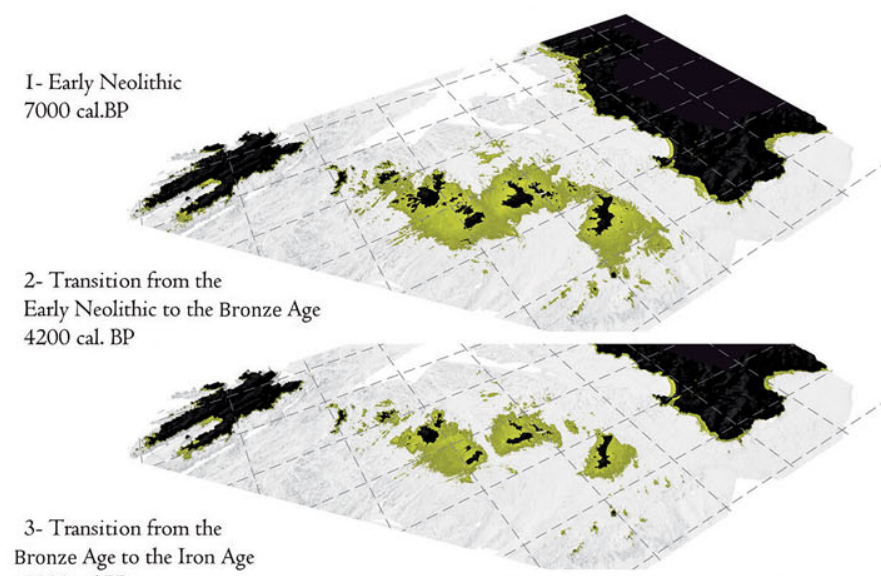

Bronze Age to the Iron Age

2800 cal.BP
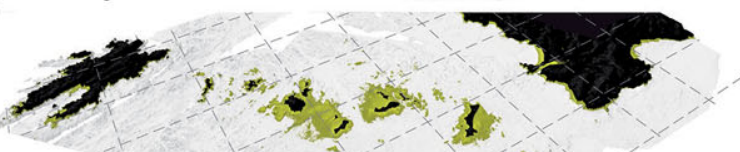

4- Gallo-Roman period 2000 cal.BP
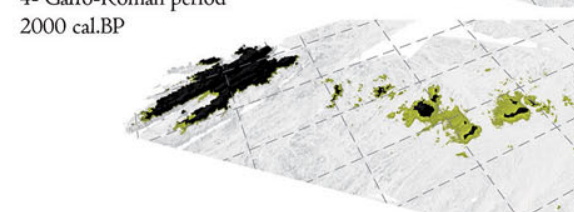
$y^{2}=$

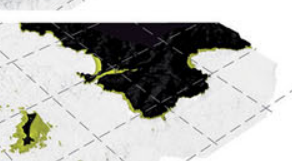

5- Present-day

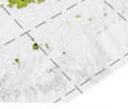

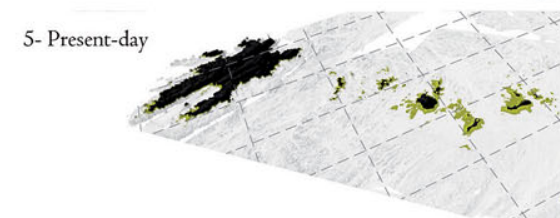
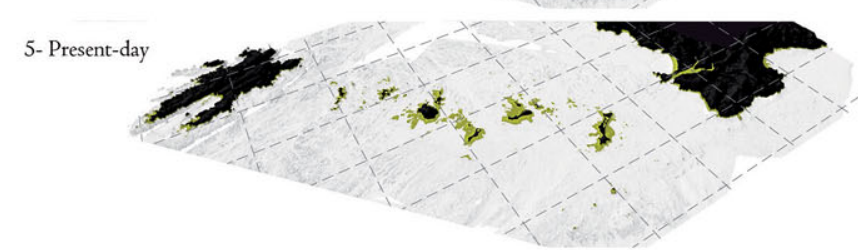

Figure 3. Paleogeographic changes induced by the relative sea-level rise from the early Neolithic to the present-day: $A$ ) RSL data from the western Brittany (data from Stéphan and Goslin, 2014; Goslin et al., 2015; Stéphan and Laforge, 2015; Stéphan et al., 2015); B) terrestrial area losses due to the gradual inundation of the Molène plateau (after Pailler et al., 2014: 114, 7); $C$ ) foreshore area losses (after Pailler et al., 2014: 114, 7); D) Paleogeographic reconstruction obtained from the simulation of the RSL rise (after Pailler et al., 2014: 113, 6).

also provide an insight into these insular populations' diet and methods of resource use. The vast majority were turned seaward, as one could expect for an insular population. Besides these specific and quite logical traits of the insular diet, everyday life on these islands was very similar to that on the continent to the east. All the standard traits of mainland Neolithic culture (agriculture, animal breeding, new technical systems, megalithic funerary monuments, and so on) are found on the islands, moreover some imports of material from the continent have been highlighted (Pailler et al., 2014).

\section{Methodology}

In order to enrich the available data about the tidal weirs, and to establish links with the archaeological sites excavated on the islands, a preliminary inventory of the sub- and intertidal potential tidal weirs of the Molène Archipelago was established. Several methods were used including analysis of the local marine toponymy, the study of historical sources (ancient maps and aerial photographs), the acquisition of bathymetric surveys, and some foreshore survey. In a second step, intensive field surveys, from diving to walking the foreshore, were conducted on the most evident structures to confirm their anthropogenic nature.

\section{Toponymy and oral sources}

The names of the different rocks, bays, currents, and channels, are very informative about the location of tidal weirs, especially along the coast of Brittany where 
place-names referring to this specific fishing practice are generally indicated by the Breton term gored (Madeg et al., 2004; Langouët, 2008). However, the literal translation of this term in the French language resulted in the emergence of new derivative place-names on historical documents. Due to the similarity between the Breton term gored and the French term goret (meaning 'pig', or rather 'pigling'), other place-names related to pigs, such as goret, cochon, porc, pourceau, are also potentially indicative of the presence of tidal weirs (Langouët, 2008).

An investigation was also conducted among the local population, particularly among the many shellfish gatherers living on the islands. Their empirical knowledge of the foreshore provided sometimes valuable information on the location of archaeological remains. This first-hand information was a major consideration when defining survey areas.

\section{Airborne survey}

The use of aerial photographs to detect fish traps along the coasts of Brittany was initiated by MY. Daire and L. Langouët (2010). This work was based on the observation of a large set of aerial photographs produced by the Institut Géographique National (IGN) from 1929 to the present-day. Only tidal weirs that could be observed on several different photos were noted in order to avoid confusion with seaweed accumulations or rocky bars. This method is particularly reliable on sandy seafloors, but was much more difficult to implement in the rocky areas such as the Molène Archipelago. The anthropogenic structures were difficult to distinguish from the seafloor due to a homogeneous cover of seaweed, and limited visibility through the sea water. In some places, intertidal and subtidal sand dunes may partially mask or completely bury structures, which also make their detection very difficult.

\section{The topo-bathymetric surveys}

Bathymetric surveys are a very precious tool to spot underwater archaeological objects, especially in the Iroise Sea where water turbidity and seaweed cover limit observations from aerial photographs. In this study, a large number of bathymetric anomalies that could correspond to tidal weirs were identified using the topobathymetric data from the Litto3D ${ }^{\circledR}$ project (Pastol et al., 2007; Donato, 2010) produced by the IGN and the Hydrographic and Oceanographic Service of the French Navy (SHOM). In the Molène Archipelago, topographic data are derived from LIDAR surveys (HawkEye IIa sensor) performed at low tide between 5 April and 13 May, 2010. The horizontal and vertical accuracy is estimated to be $\pm 1 \mathrm{~m}$ and $\pm 0.25 \mathrm{~m}$ respectively. The data cover the terrestrial areas and most of the foreshore area. Subtidal zones were covered from three bathymetric surveys performed by the Institut Français de Recherche et d'Exploitation de la Mer (IFREMER) with the vessel V/O Haliotis between August 2010 and September 2011 (Cordier, 2012; Le Gall et al., 2014). The data were obtained with a multibeam sensor GeoSwath sonar with a high frequency $(250 \mathrm{kHz})$. The vertical accuracy is $\pm 0.10 \mathrm{~m}$ and the horizontal accuracy is less than $\pm 1 \mathrm{~m}$. The topobathymetric data were mapped on the French Geodetic Network RGF93 and to the French altimetric system IGN-1969. The conversion of elevations relative to tide levels is obtained from reference tables produced by SHOM (2013). From the raw data, a set of $2 \times 2 \mathrm{~km}$ Digital Elevation Models with a $1 \times 1 \mathrm{~m}$ resolution was produced using Kriging's gridding interpolation method.

\section{Foreshore and underwater visual surveys}

The foreshore and underwater surveys were organized in the Molène Archipelago (Gandois et al., 2011, 2013a, 2015a) under the auspices of the DRASSM (Département des Recherches Archéologiques Subaquatiques et Sous-Marines). These field observations were considered as an absolutely essential phase: i) to avoid confusion with rocky bars or seaweed deposits; ii) to confirm the anthropogenic nature of structures suspected from toponymy, oral sources, aerial photographs, and topo-bathymetric surveys; iii) to document the architecture and the construction practices of used for tidal weirs.

Several foreshore surveys were undertaken during the winter seasons when the visibility and accessibility of the structures is improved by reduced seaweed cover. However, time spent on the foreshore was unavoidably limited to a maximum of one hour during the low tide slack and the proportion of the foreshore prospected by this means remained relatively restricted. Moreover, tidal weirs generally maintain an impressive coat of seaweed and are difficult to spot among the rocks when disturbed by the waves and tidal currents, especially the damaged or small-sized structures (Fig. 4). Consequently, foreshore survey cannot be considered as a very efficient means to spot tidal weirs and needs to be used in combination with an initial study of the local topography to locate likely areas for tidal weirs to have been built.

Extensive underwater surveys were also difficult to plan in the Iroise Sea because of the fast-changing weather conditions, wave regime and tidal currents, water turbidity, and the presence of widespread algae coverage. Consequently, dive campaigns were limited to the most obvious objects indicated by islanders, and spotted on aerial photographs or bathymetric surveys. The aim of these underwater observations was solely to establish the anthropogenic nature of structures, the presence of a line of contiguous standing stones being the discriminating criterion.

\section{Preliminary inventory}

A total of 22 possible stone tidal-weir sites were recognized in the first phase (Table 1). 


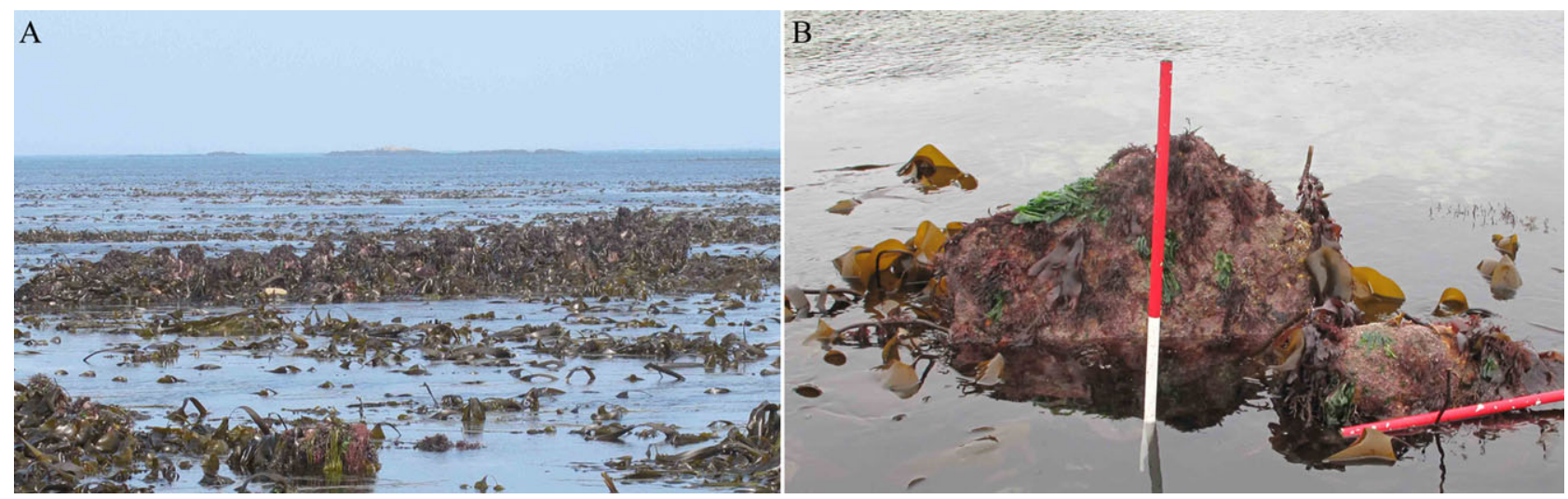

Figure 4. A) View of the seaweed totally covering the fish weir Ar Cuisnier; B) view of the pinkish concretions (Lithothamnion purpureum) covering the stones on Roc'h Uspern (H. Gandois).

\section{Toponyms and oral sources}

Two tidal-weir toponyms containing the traditional term gored were recognized on the Molène Archipelago from the analysis of several hundreds of place-names (Madeg et al., 2004): Kost Ar Gored (Table 1, no. 16) and Beg Ar Gored (Table 1, no. 17). In addition, two reefs, Le grand pourceau and Le petit pourceau, could potentially be linked to tidal weirs. The overall number of toponyms is very low in comparison with the mainland foreshores.

Thanks to informal discussions and interviews with the shellfish gatherers who invade the foreshore during the equinox tides, useful indications about the location of five submerged archaeological sites were collected. One of the tidal weirs on Kemenez was described as an 'alignment of small menhirs (standing stones)' (Table 1, no. 4). Other evidence of the presence of anthropogenic remains on the foreshore was provided by two tourists fishing at low tide in the northern Kemenez Island (Table 1, no. 7). Two abalone scuba-diving fishermen mentioned the existence of some 'strange standing stones' north-east of Kemenez (Table 1, nos 8, 9). Two islanders also reported seeing some stones in the western part of Molène Island during the spring equinox tides in the 1980s, which had been interpreted as the 'dyke of a very old harbour' (Table 1, no. 14). Finally, standing stones quite low on the foreshore, north-west of Béniguet Island were mentioned by another source.

\section{Objects detected from aerial photographs}

A total of eight potential archaeological objects were spotted from the detailed observation of historical aerial photographs. The most obvious evidence of the presence of submerged structures was obtained on sandy seafloors. To the west of Molène Island, two curvilinear objects are visible on the photographs from different air campaigns from 1929 to 2005 (Fig. 5A-D, Table 1, nos 14, 15). Two parallel structures $c .100 \mathrm{~m}$ long were easily identified north of Kemenez Island (Fig. 5 E-F, Table 1, nos 8, 9). Four other structures have also been seen on rocky bottoms and in deep-water areas (Table 1, nos 1, 19, 20, 22).

Among the eight structures seen on aerial photographs, only three have been definitively confirmed as anthropogenic structures (Table 1, nos 1, $8,9)$, another two seem very likely to be tidal weirs (Table 1, nos 14, 15). The last three are more than doubtful: nos 19 and 22 are, for the part observed, simple accumulations of stones lying on the seafloor; $\mathrm{n}^{\circ} 20$ has been observed on only one photograph and its location makes it an unlikely tidal weir. Thus, although this method is efficient, it should always be supported by visual survey to confirm or refute the initial hypothesis, as images of natural rocky bars can be easily confused with anthropogenic structures.

\section{Bathymetric anomalies from LIDAR survey}

A total of seven bathymetric anomalies were detected using high-resolution DEMs derived from airborne LIDAR and multibeam surveys (Fig. 6, Table 1, nos $2,3,8,9,11,12$, and 18). Of these, two had already been spotted on aerial photographs (Table 1, nos 8, 9). Anthropogenic structures were distinguished from natural marine relief features by a simple visual analysis of the seafloor bathymetry. On sandy seafloors, anomalies correspond to rectilinear ridges that locally stand out from the flat surfaces of the marine sediment cover (Fig. 6C). On rocky seafloors, stone tidal weirs were easily spotted from DEMs by their orientation being out of line with the geological structure (Fig. 6D). A doubt concerns the anomaly of $\mathrm{Kal}$ ar Charko (Table 1, no. 18) because the orientation of the ridge, perpendicular to the current foreshore, is very surprising. In addition, this feature is located in a sector where the submarine cables linking Molène Island to the mainland meet (Gandois et al., 2013a).

These initial results concern the structures best preserved in elevation or the most visible in relief. Further work is required to explore the LIDAR data in more detail using different visualization techniques. Moreover, the spatial resolution of the topo-bathymetric data used limits the detection of 


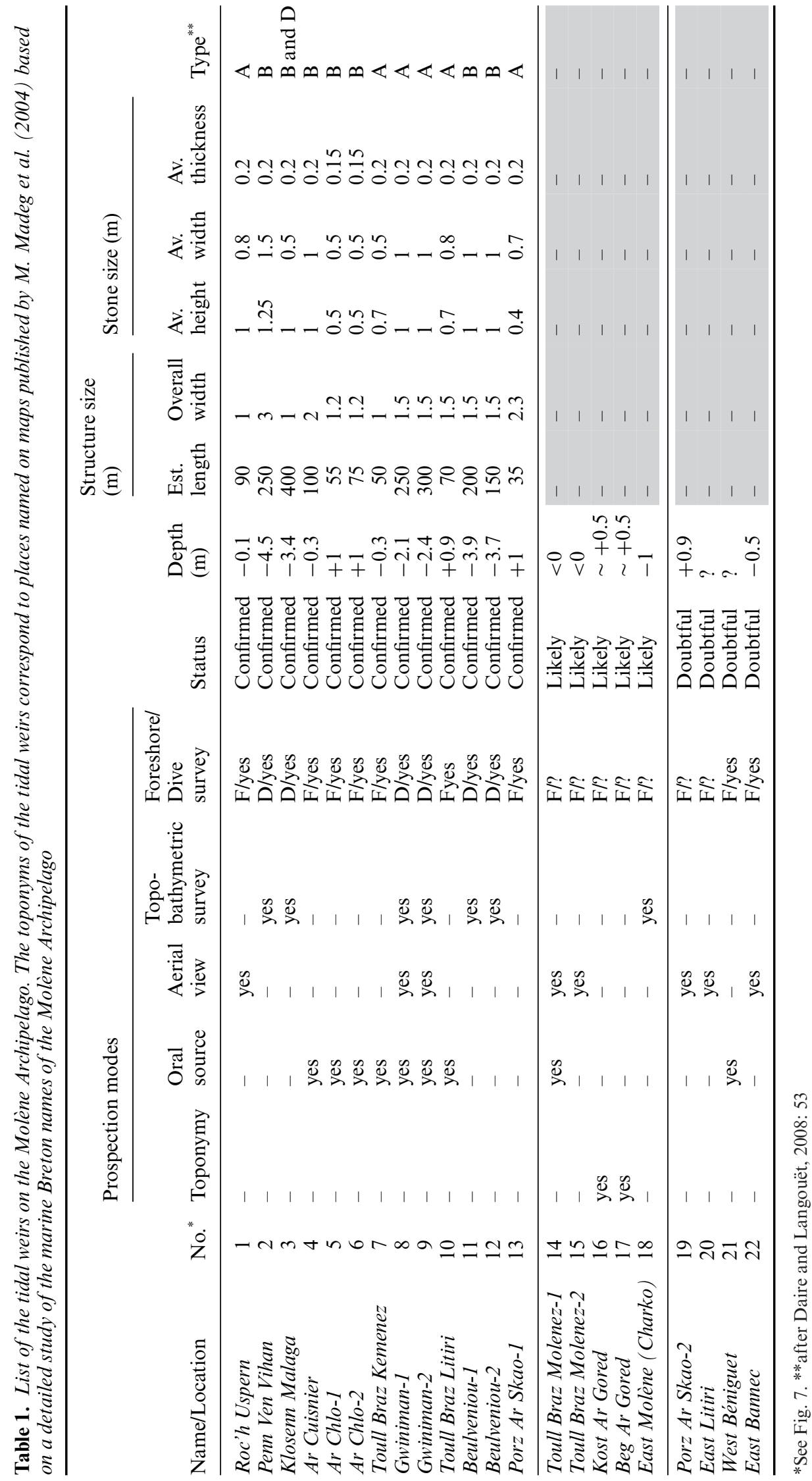




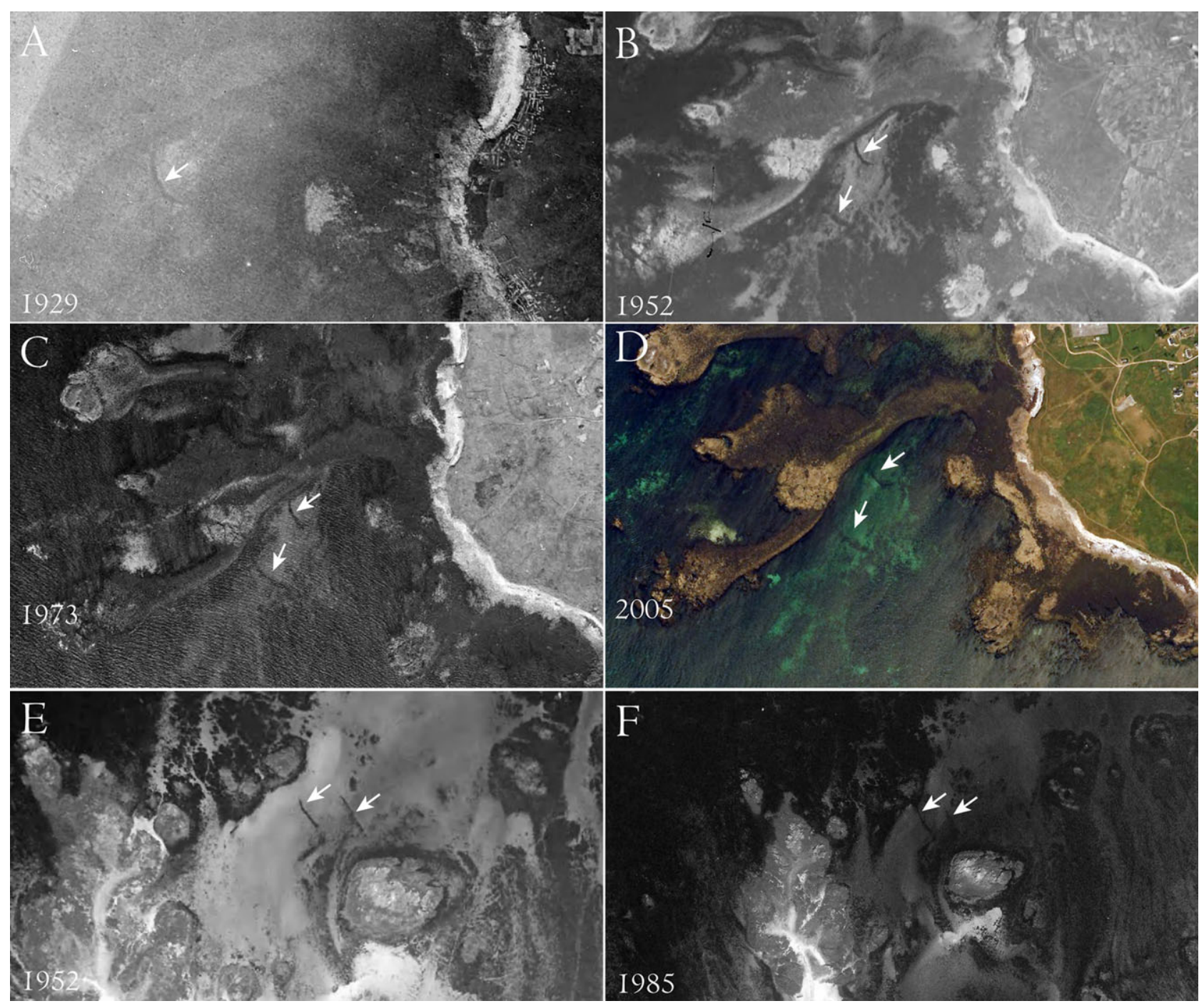

Figure 5. Aerial detection of stone tidal weirs from the observation of historical photographs. Object spotted in the south-west of the Molène Island on several aerial views taken in: $A$ ) 1929 ; B) 1952 ; C) 1973 ; D) 2005 , structures detected close to the Gwiniman reefs from photos taken in $E$ ) $1952 ; F$ ) 1985 (all courtesy of IGN).

small-sized archaeological remains. Such structures can only be discovered from intensive field survey.

\section{Confirmation from archaeological observations}

A total of 13 stone tidal weirs were confirmed (Table 1), five anthropogenic structures are deemed likely and need more field observations, four locations were categorized as doubtful due to the absence of any direct evidence.

The field surveys conducted on the foreshore at the two locations containing the Breton term gored provided no firm evidence of any anthropogenic structures, although Kost Ar Gored (Table 1, no. 16) and Beg ar Gored (Table 1, no. 17) are attributed to the small depressions in the foreshore that are particularly favourable to the construction of fish traps. In this area, the artificial deepening of the channel between Molène Island and its islets in the 1960s led to erosion over the past decades. This change in coastal morphology could be responsible for the destruction of any structures that existed, so the sites are not definitively confirmed as tidal weirs, only likely ones.

The two reefs containing the term pourceau are located on the margin of the deep Helle Channel, in the eastern part of the Molène Plateau. The minimum depth of the reefs is $5 \mathrm{~m}$ below sea level. No dive surveys were conducted in the vicinity of these sites but we consider the presence of tidal weirs in the area to be very unlikely due to the depth of the seafloor and the distance to the closest island. Moreover the surrounding rocks all have animal names: Le veau (the calf), Le cerf (the deer), Le lapin (the rabbit), Le bruf (the ox/bull), and so on, so the presence of a pourceau (pig) is unsurprising. For these 


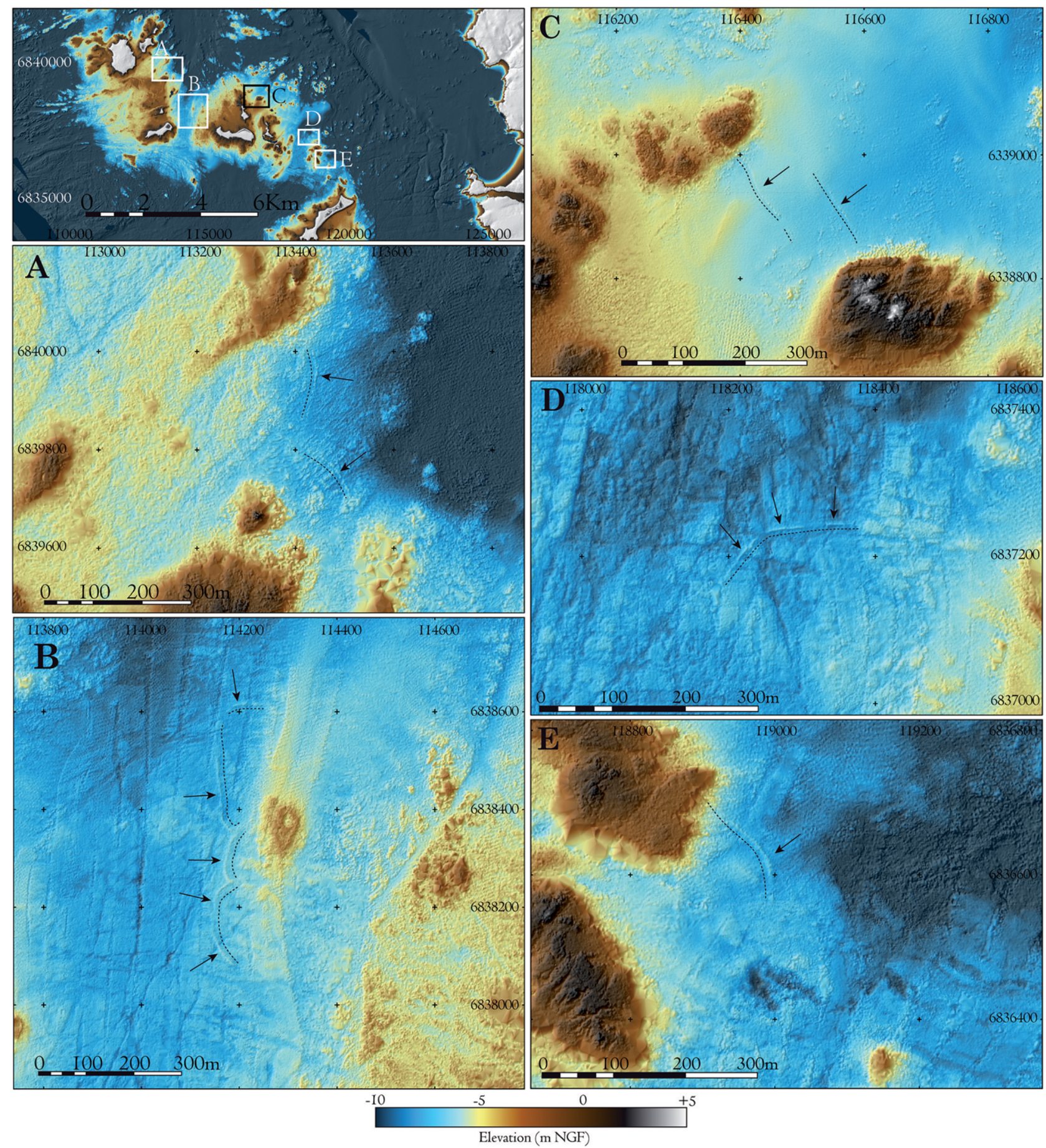

Figure 6. Bathymetric anomalies spotted from the digital elevation model derived from LIDAR and multibeam echosounder data in the Molène Archipelago: A) Penn Ven Vihan anomaly (Table 1, no. 2); B) Klosenn Malaga anomaly (Table 1, no. 3); C) Gwiniman-1 and Gwiniman-2 anomalies (Table 1, nos 8, 9); D) Beulveniou-1 anomaly (Table 1, no. 11); E) Beulveniou-2 anomaly (Table 1, no. 12).

reasons, these two locations are not included in the inventory.

Oral testimonies collected from the inhabitants of the archipelago enabled the discovery of eight tidal weirs, of these five had not be recognized by other means. Only the stones described on the north-west of Béniguet Island were not found, despite several surveys conducted during the spring and autumn low tides. These results highlight the usefulness of oral sources for archaeological surveys. Despite their scarcity, such 

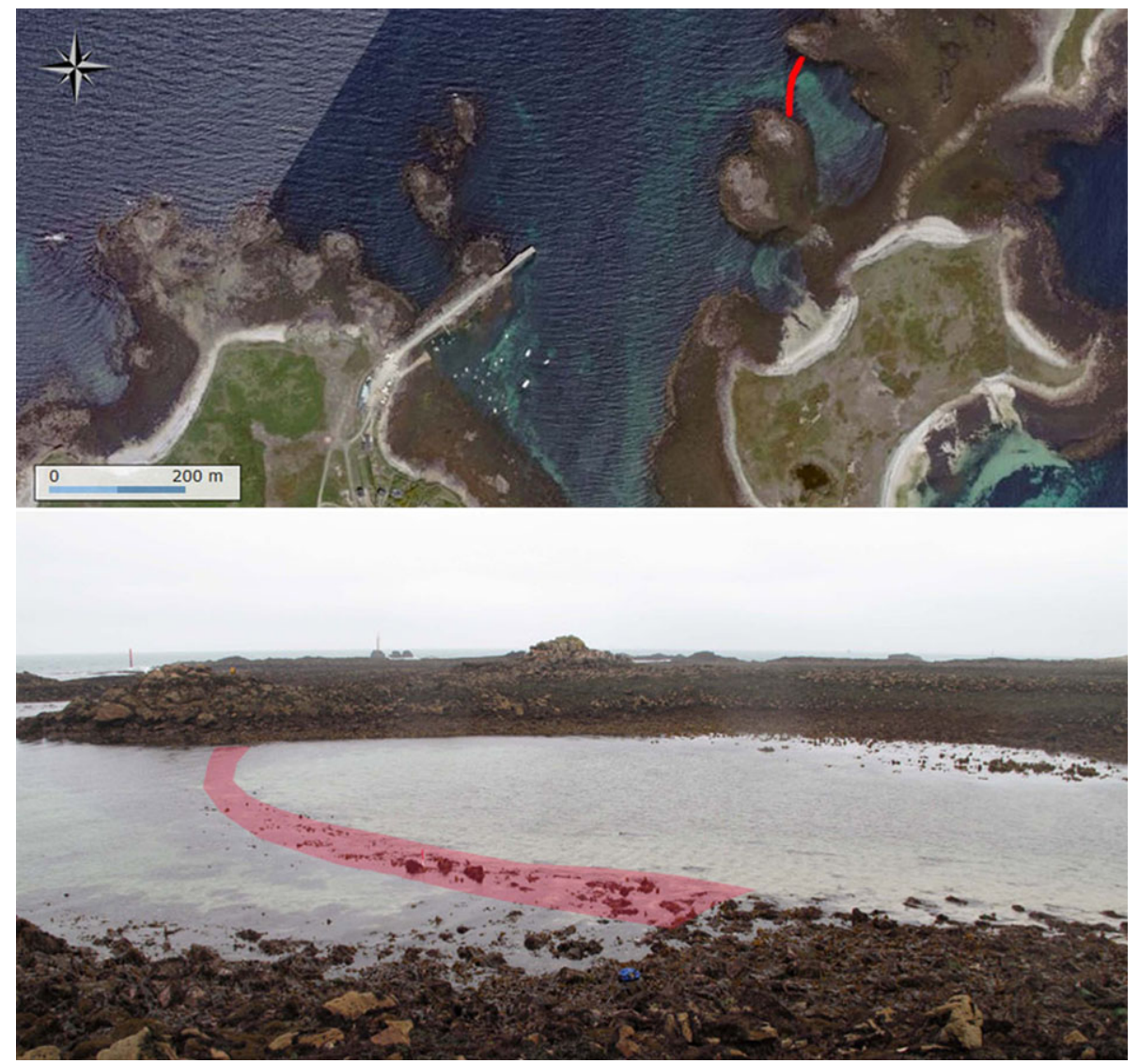

Figure 7. Top: aerial view of the fish trap Roc'h Uspern (courtesy of IGN); bottom: view towards the north-east of the same structure: in both cases the fish weir is highlighted in red (H. Gandois).

information is invaluable in defining a strategy for field intervention, especially on foreshores where work is time-limited by the tide. This first-hand information has to be taken very seriously into account, the islanders and/or fishermen have detailed knowledge of the foreshore, and the majority of them are able to tell when the disposition of rocks does not seem natural. On the other hand, their interpretations of these structures must be considered with much more caution, as the characteristics of stone tidal weirs are now almost unknown to local fishermen.

Of the eight structures recognized on the aerial photos, three were attributed to anthropogenic structures and tidal weirs. The first one (Roc'h Uspern Table 1, no. 1) is located north of Molène Island's islet and was documented during the equinox tides of spring 2012 from a foreshore survey (Fig. 7). Two others (Gwiniman-1 and Gwiniman-2, Table 1, nos 8,9) are located in the seafloor surrounding Kemenez Island and correspond to two very long and parallel rocky bars (Figs 5E-F, 6C) surveyed with dives in June 2011. Two structures detected from aerial views have not yet been documented (nos 14, 15); however, the presence of tidal weirs is strongly suspected because of their favourable location and their recurring appearance on several historical aerial photographs. One of them was also mentioned by a local shellfish gatherer (Table 1, no. 14). Lastly, three structures previously suspected from aerial photographs (Table 1, nos 19, 20, 22) were excluded from the inventory due to the lack of evidence on the ground and probable confusion with natural rocky bars (Fig. 8).

Considering that a visual survey is needed to determine the nature of the detected structures, several dive campaigns were carried out on four sites identified only from bathymetric data. These sites correspond to the most obvious anomalies in seafloor morphology. The first underwater surveys were obtained during several short dives in May and June 2012 on the sites of Klosenn Malaga (Table 1, no. 3), and Beulveniou-1 (Table 1, no. 11). The observation window was limited to an average of 10 minutes during the low tide slack in order to avoid currents that can reach 3 knots at flood tide and 4 knots at ebb tide in these areas. Nevertheless, these operations revealed that all the stones were within built structures. In 2016, other dive campaigns were undertaken on the sites of Penn Ven Vihan (Table 1, no. 16) and Beulveniou-2 (Table 1, no. 12). Despite bad weather conditions, photographs and films were taken that confirm the anthropogenic nature of the 


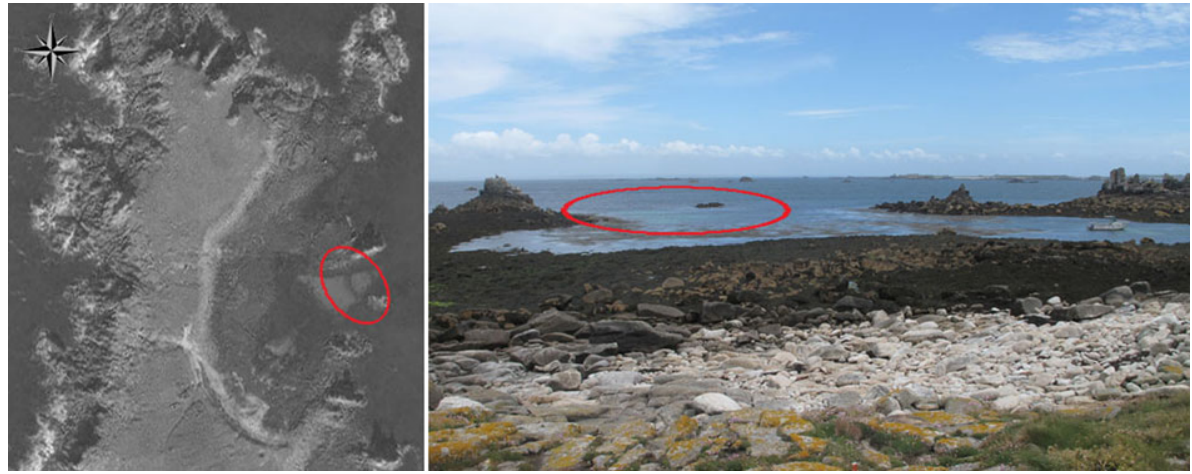

Figure 8. Left: aerial photograph of Bannec (courtesy of IGN); Right: view towards east of the small inlet; in both cases the rocky bar is visible (H. Gandois).

bathymetric anomalies as lines of contiguous standing stones, and provide information about the erosion of the stone constructions by the tidal currents. Only the structure located north of the island of Béniguet, Porz Ar Skao-1 (Table 1, no. 13), was found only by means of foreshore survey. One must keep in mind that these structures are very particular and a highly trained eye is necessary to spot them on the foreshore among the seaweed cover and rocks disturbed by tidal currents. This method cannot be considered an efficient means to spot tidal weirs, and should be used in conjunction with a study of local topography to suggest areas where such structures were most likely to have been built; as will be seen the locations were always carefully chosen.

\section{Construction and morphology}

The main characteristic of the archipelago's tidal weirs is that they are all made of standing stones. This observation could, however, be an effect of the differential preservation of different types of tidal weirs. Stone is more likely to resist the assaults of both time and sea compared to constructions made of organic materials. All the structures that have been documented offer very similar characteristics but with some slight variants. With one exception, the standing stones are placed parallel to the axis of the trap, either with a main central row as at Klosenn Malaga; two main external rows as at Roc'h Uspern or Toull Braz Kemenez; or up to seven parallel rows as at $\mathrm{Ar}$ Cuisnier (Fig. 9A).

Some stones still stand perfectly vertical, but generally they are at a steep angle to either side of the structure. We propose that most of the inclined stones have slumped to these positions as a result of the swell and strong currents. In at least three cases, however, (Gwiniman-1 and 2 and Penn Ven Vihan), the stones appear to have been intentionally splayed to form a quarter-circle (Fig. 9E) showing a slight variation in the construction mode. When this disposition is adopted, the vertical stones are always located towards the higher part of the foreshore, apparently to ensure the fish could be trapped and easily gathered.
Measurements for the visible parts of the stones (the underground dimensions remain unknown) can reach more than $1 \mathrm{~m}$ in height and width for Penn Ven Vihan, while in the case of $\mathrm{Ar}$ Chlo-1 and 2 these figures barely reach $0.30-0.50 \mathrm{~m}$. In contrast, the thickness of the stones used is extremely standardized whatever the overall size of the tidal weirs and commonly varies between 0.15 and $0.20 \mathrm{~m}$. When it was possible to identify the geological nature of the stones, it always matched the type of rock locally available in the immediate area, granite in the north around Molène, and gneiss in the south around Kemenez and Béniguet.

In all cases when the observation was possible, the blocking device between the main standing stones was always extremely well disposed with a very dense packing of small elongated pebbles (Fig. 10). The aim was to leave as few voids as possible between the standing stones in order to provide a dense and compact volume able to resist the twice-daily tides.

Tidal weirs with a mass of small blocking stones placed between two external rows of standing stones are known on the continent at Santec, Finistère (Roué and Le Goff, 2008), but the presence of several rows of parallel standing stones is rare and appears quite specific to the Iroise Sea. However, without formal excavation, it will remain extremely difficult to know if these several rows are the result of different stages of construction, repairs, or part of the original structure.

The only fish trap with a markedly different construction mode is Porz Ar Skao-1, located on the northern foreshore of Béniguet (Fig. 11, Table 1, no. 13): here the standing stones are perpendicular to the structure's axis, not more than $0.40 \mathrm{~m}$ high, and positioned so that they abut each other (Fig. 12), whereas in the other tidal weirs the standing stones are more loosely arranged, parallel to the structure's axis and up to $1 \mathrm{~m}$ in height. There are two possible explanations for these differences: first the Porz $\mathrm{Ar}$ Skao-1 structure is simply not a fish trap but rather a fish pond; second, as it is the most recent in date (Medieval period, see below), the constructions method 

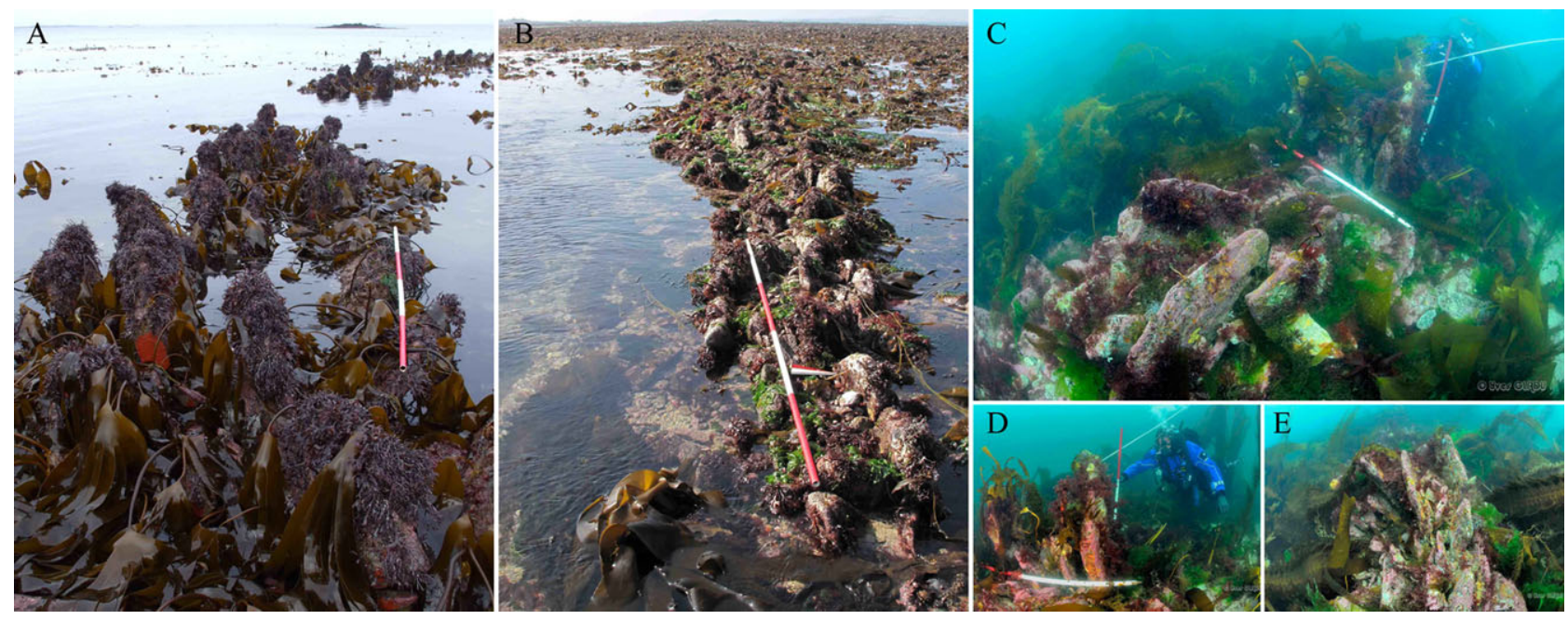

Figure 9. A) close-up view of the fish weir Ar Cuisnier with up to seven rows of standing stones; B) close-up view of the fish trap Ar Chlo-2, with four rows of standing stones (H. Gandois); $C-D-E$ ) different views of the half-fan disposition of the stones in the fish trap Gwiniman-1 (with permission, (C) Y. Gladu).

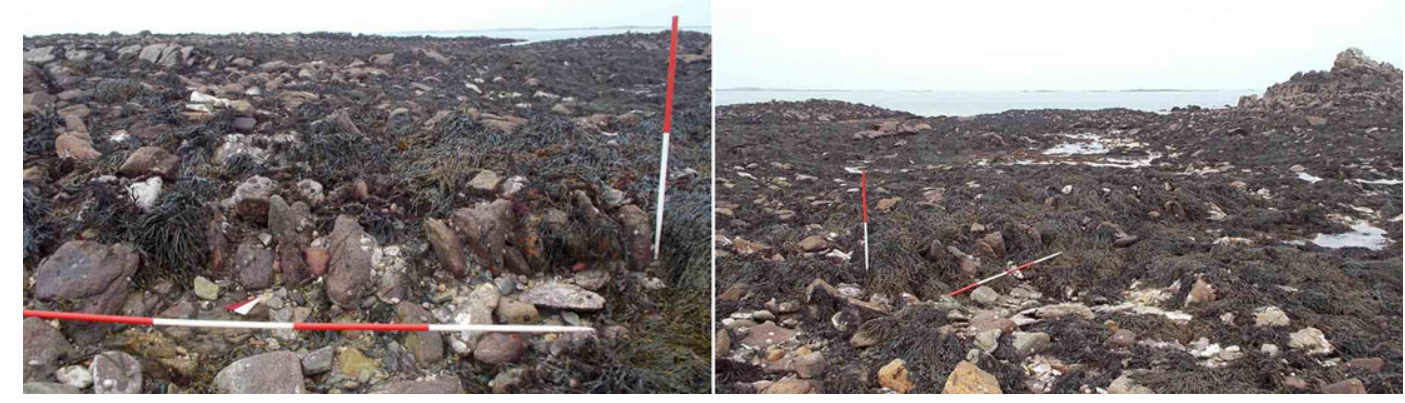

Figure 10. Two close-up views of the blocking device between the standing stones in the fish weir Ar Cuisnier. (H. Gandois)

had simply changed. We tend to favour the first hypothesis, but as yet lack evidence to prove it.

Most of the structures have been severely damaged by time and by sea, not a single structure is undisturbed, with some being almost completely destroyed, such as Toull Braz Litiri, while others do have very wellpreserved sections, such as Ar Cuisnier or Gwiniman-1 and 2. Due to damage, the lengths proposed in Table 1 are only estimates, but should nevertheless be close to the reality at the time when these structures were in use. Putting aside the unusual structure of Porz Ar Skao-1, the dimensions of the tidal weirs vary from $55 \mathrm{~m}$, for $\mathrm{Ar}$ Chlo-1, up to $400 \mathrm{~m}$ for Klosenn Malaga; however, this last structure is in fact composed of three different parts (Fig. 6B). The longest unique fish trap, Gwiniman-2, is nonetheless approximately $300 \mathrm{~m}$ long. Quite logically, the stones constituting the rows in the structures are larger for the longest ones.

Nowhere has it been possible to identify an opening or sluice in the structures, although this statement must be heavily tempered by the sometimes severe damage seen on the weirs, all the more since an opening would be a weak point, the most likely to break in the first place. The device, generally made of wood even in the case of stone tidal weirs, helps to channel the water, concentrating the fish in this area, thus facilitating collection. Nevertheless an opening is not a requirement for a fish trap to operate properly; it seems likely that most, if not all, tidal weirs in the Iroise Sea lacked this device.

Based on the typology of tidal weirs established by Daire and Langouët (2008: 53), with one exception, all the structures on the Molène Archipelago belong to the type A or B. Type A concerns the traps placed between two rocky outcrops emerging from the foreshore (Fig. 13B, right). Type B is roughly the same but without any large rocks at the extremities the construction only leans on a rocky plateau behind it (Fig. 13A). The rocky spurs at the ends of the tidal weirs can be very prominent, such as in the case of Roc'h Uspern (Fig. 7), or for the two structures Gwiniman1 and 2. In the Iroise Sea, the abundance of rocky outcrops forming small bays on the foreshore offers a very favourable environment to place fish traps. The weirs are generally curvilinear, the convex side turned towards the sea (with the exception of $A r$ Chlo-2); 


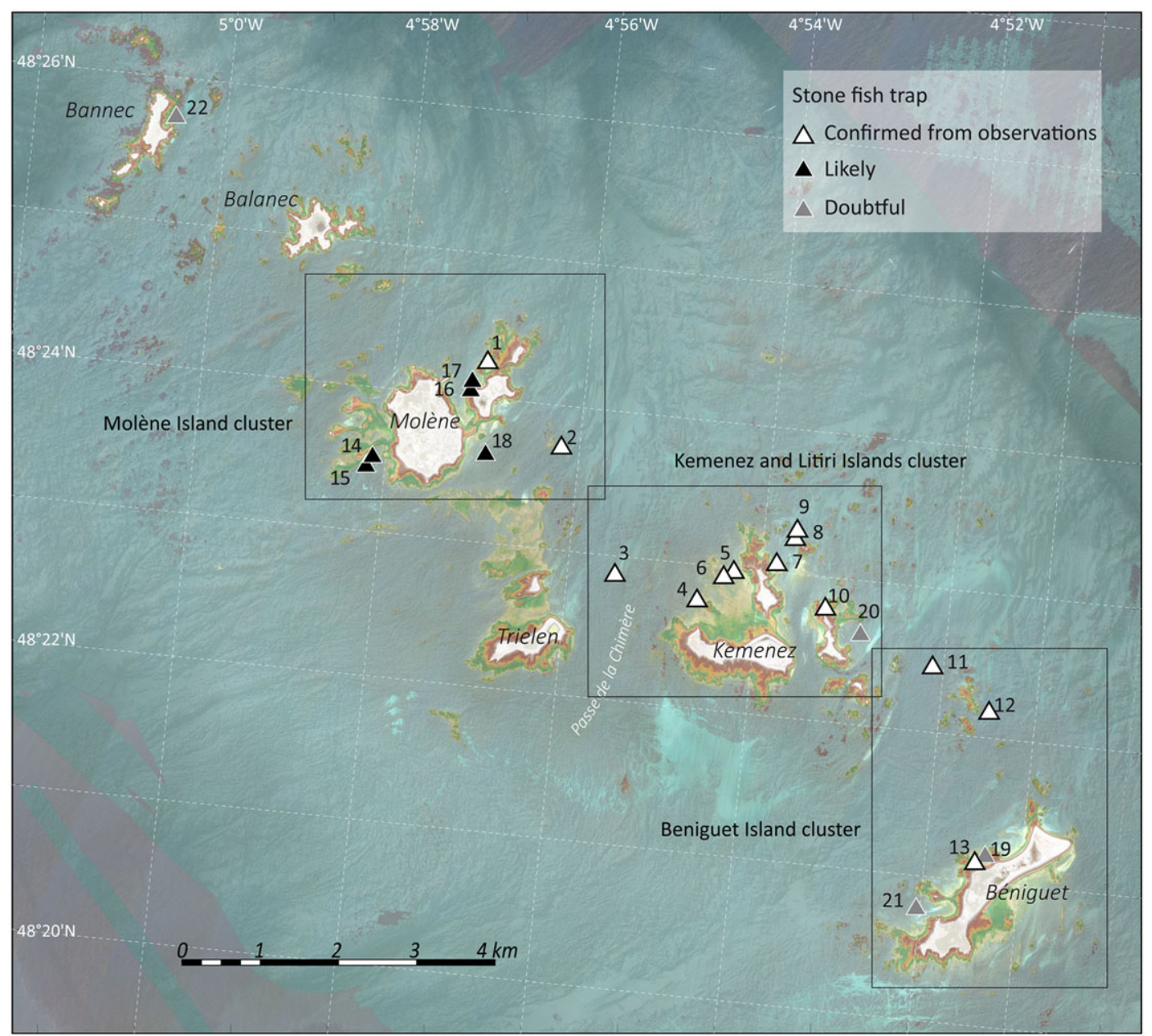

Figure 11. The Molène Archipelago: location by zone of the different tidal weirs, confirmed (nos 1 to 13), likely (nos 14-18) and doubtful (nos 19-22) (CAD P. Stéphan).

their general axis is perpendicular to the slope of the foreshore thus optimizing the capture of fish during the ebb tide.

The exception is the northern structure of Klosenn Malaga, which belongs to type D (Daire and Langouët, 2008: 53); in this case the fish trap is not closed, but the fish are gathered and concentrated in the southern part of the construction by the ebb current, which runs from north to south here (Fig. 6B).

Despite this slight variation in the typology, and excluding the fish trap (or fish pond?) of Porz $\mathrm{Ar}$ Skao-1, all the tidal weirs documented on the Molène Archipelago offer some broad common features: standing stones are placed parallel to the general axis of the structure in up to seven rows of stones, with a very dense blocking device, using very local raw material (that is stones found directly on the foreshore), with no recognized sluice or opening in the central part. The main differences noted concern the size of the structures and their depth too, variables that are demonstrably linked.

\section{Discussion}

Dating

No conventional radiocarbon methods can be used to date the stone tidal weirs because of the absence of well-preserved organic material built into their walls (Baltzer et al., 2010; Cassen et al., 2011). In fact, in the case of the Iroise Sea, no organic material has been found at all. Nevertheless, Daire and Langouët (2011) proposed an alternative approach to estimate the period of construction, assuming that the tidal weirs have been strategically installed on the foreshore in order to optimize fish catches and fishing practices. The most suitable location to build a fish trap (or the place from which fishing will be the most profitable) depends mainly on the elevation (or depth) of the structure according to the tidal frame. Based on archaeological excavations and historical archives, Daire and Langouët $(2008,2010)$ deduced two main rules of construction for stone tidal weirs on the foreshores of Brittany taking into account the local 

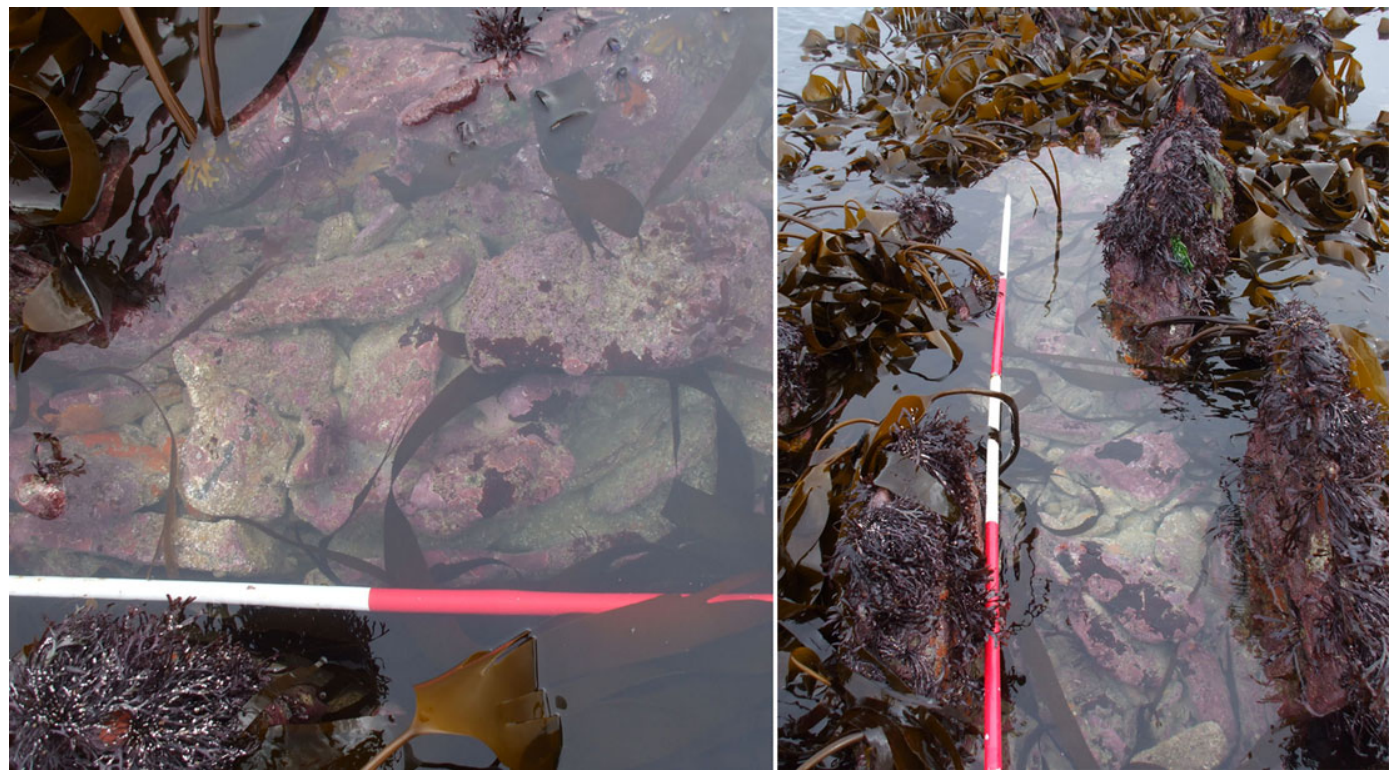

Figure 12. Two close-up view of the structure Porz Ar Skao-1, note the orientation of the stones perpendicular to the general axis. (H. Gandois)
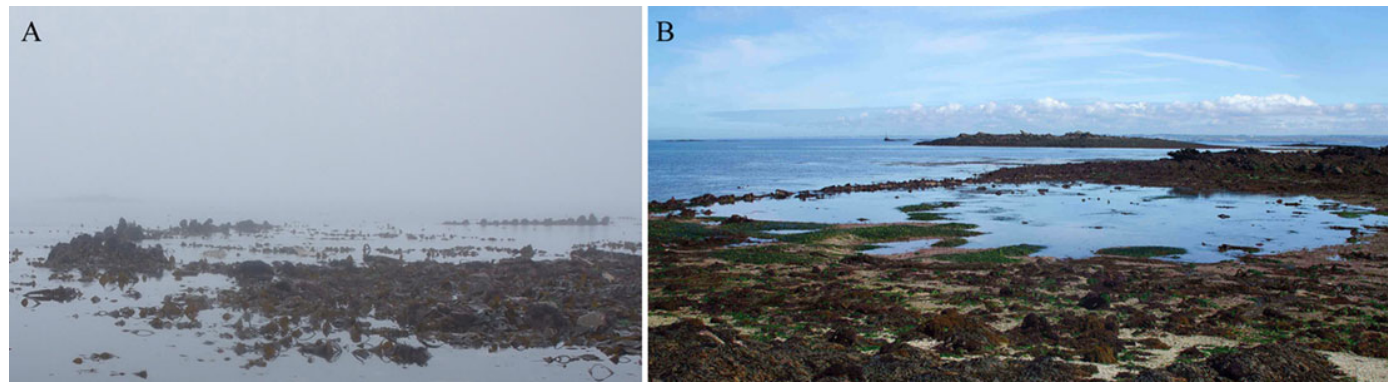

Figure 13. A) Ar Cuisnier example of a type B fish trap; B) Toull Braz Kemenez: example of a type A fish trap as described by Daire and Langouët (2008: 53) (H. Gandois).

tidal frame. The first rule assumes the base of the walls $(\mathrm{Wb})$ was constructed above the mean low water neap tide (MLWNT) level to practice fishing whatever the tidal conditions. The second rule of construction assumes the top of the walls (Wt) never exceeded the mean high water neap tide (MHWNT) level to ensure that fish entered the trap at every tide. Although a large part of the walls are eroded now, their initial height was estimated at a mean average of about $1 \mathrm{~m}$ from several archaeological excavations and written sources dated to the Middle Ages (Daire and Langouët, 2008). Again, this condition appears to be met by fish-trap builders. Therefore, the elevation of the traps relative to tide levels can be defined as follows:

$$
\text { MLWNTt0 }>\text { Wb }>\text { MHWNTt0 }-1 \mathrm{~m}
$$

where MLWNT and MHWNT are respectively the lowest and highest positions of the base of the tidal weirs on the foreshore at the time of their construction (t0). Assuming these two rules were respected by coastal communities over the time, we used the Holocene relative sea-level points produced in Western Brittany to estimate the values of the MLWNT and MHWNT during past millennia (Fig. 14). Some studies have highlighted significant changes in tidal range along the European coasts during the Holocene (Uehara et al., 2006; Neill et al., 2010) with possible effects on the extent of foreshore areas. For this reason, the paleotide model developed along the Atlantic and English Channel coasts (Neill et al., 2010) was used to correct the effects of tidal range variations. The past mean spring tide range model was compared to the present-day value calculated from tide gauges (SHOM, 2013). Finally, the difference between past and present values was added to the minimal and maximal values of tide levels.

The elevation range between these two values was used to locate the most suitable area to construct a tidal weir at different time periods (Fig. 14A-E). 


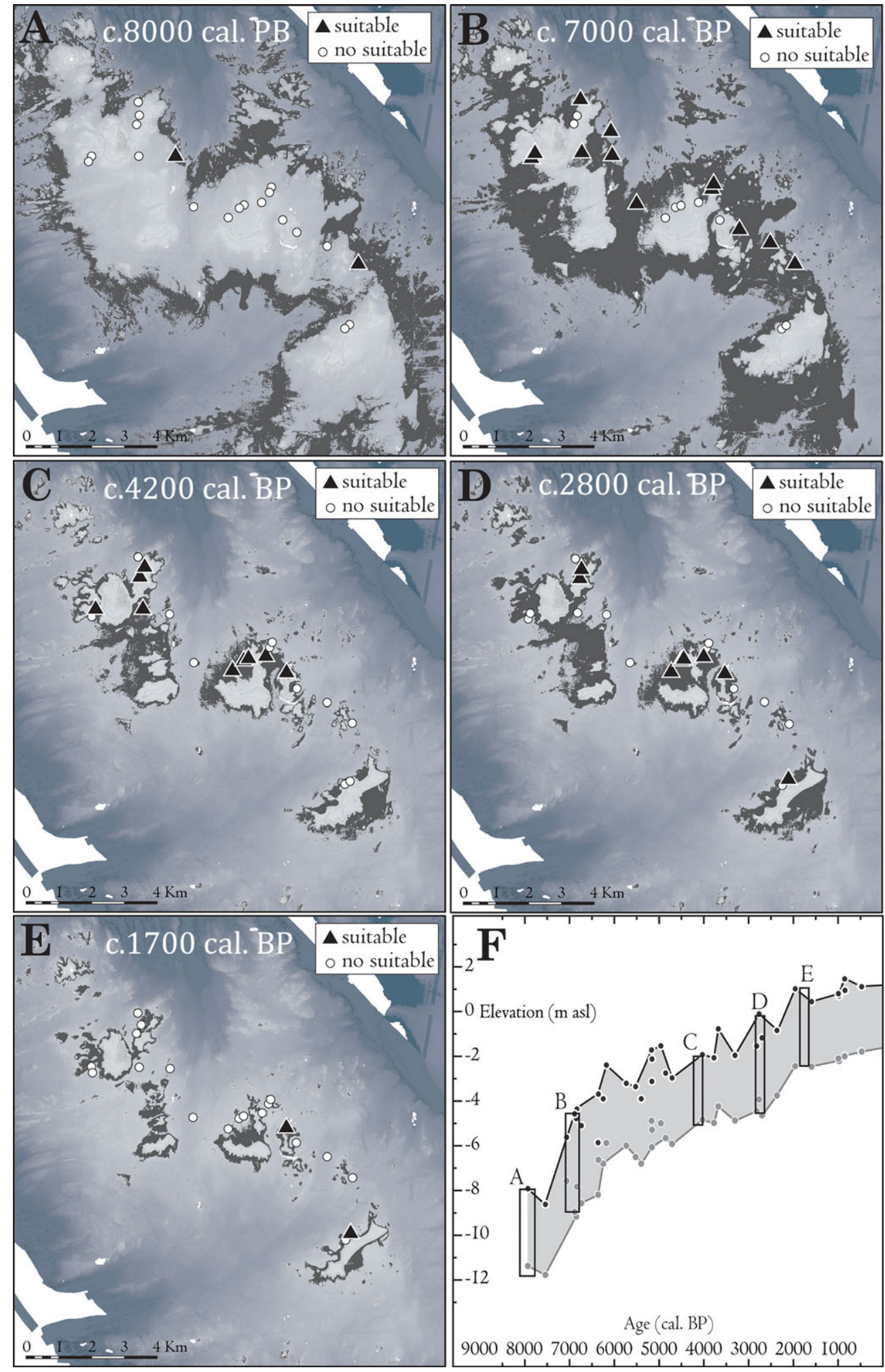

Figure 14. Digital Elevation Model of the Molène Archipelago on which dark grey areas correspond to the most suitable areas to build a stone fish weir: A) Late Mesolithic; B) Early Neolithic; C) Late Neolithic; D) Late Bronze Age; E) Gallo-Roman period; $F$ ) most suitable elevation ranges to build a fish weirs (dark grey area) assuming the construction rules proposed by Daire and Langouët (2010) were respected. Grey points and black points correspond to the MHWNT-1m and MLWNT levels respectively, derived from relative sea-level records from Western Brittany. Time windows refer to figures A to E and correspond to the elevation range used to map grey areas. 
This cartographic approach enables estimates of the period in which each stone tidal weir was constructed. Despite the low chronological accuracy of this first approximate approach, two generations of tidal weirs are identified on the inter- and subtidal areas of the Molène Archipelago.

A first generation of structures attributed to the Early Neolithic (transition between Final Mesolithic and Early Neolithic) ranges between $5600 \mathrm{BC}$ and 4200 $\mathrm{BC}$, taking into account only the median ages. The oldest stone tidal weir is Penn Ven Vihan, evidenced by the high-resolution bathymetric surveys. This structure is located at $-4.54 \mathrm{~m}$ below the present-day lowest astronomical tide level, and was built at a time when the relative sea level was about $-8.4 \mathrm{~m}+/-1 \mathrm{~m}$, that is between 5700 and $5250 \mathrm{BC}$. This could correspond to some of the oldest structures attested in the western France to date (Marchand, 2017).

A second generation of tidal weirs is attributed to the period of the Neolithic and Early Bonze Age, between $3400 \mathrm{BC}$ and $2100 \mathrm{BC}$. The depth of the stone structures are close to the present-day lowest astronomical tide level and were probably erected when the relative sea level was between -4 and $-6 \mathrm{~m}$.

\section{Density}

The inventory of the tidal weirs reflects a high density of structures, and is probably underestimated because some structures were likely eroded by waves, such as Toull Braz Litiri, now almost completely destroyed, that will disappear in the near future. On the other hand, many tidal weirs could still be unknown as the seaweed cover makes their identification very hard, especially for the smallest ones. The high number of tidal weirs (13 confirmed and documented, five more likely) is counterbalanced by the long time period in which they were constructed and used (Fig. 14). The oldest confirmed structure (Penn Ven Vihan, no. 2) could date back from the Early Neolithic, maybe even to the Late Mesolithic, while the most recent one (Porz Ar Skao-1, no. 13) is attributed to the Medieval period. The whole time-span covers almost seven millennia corresponding to more than 250 human generations.

\section{Location strategies vs taphonomy}

The structures discovered around the Molène Archipelago are located in the northern and eastern parts of the foreshore areas (Fig. 11). Whatever the exact position of the coastlines when the tidal weirs were built, these zones are sheltered from the Atlantic incident waves, which mainly arrive from the west. These locations were likely carefully chosen by the builders because of the low to moderate hydrodynamism, thus facilitating the construction and maintenance of the structures. Alternatively, the present distribution could be the result of differential preservation, those established on the west and south having been destroyed by the flows. Indeed, when looking at the map, it is surprising that no fishing structure has been discovered around the island of Trielen. Thanks to many remaining megalithic funerary monuments (Sparfel et al., 2009), we know that all the islands were inhabited from at least the Neolithic period, so the absence of tidal weirs around Trielen strongly suggests that either these are still unknown, or have been destroyed by the strong Atlantic tidal waves. Despite the lack of definitive proof, it is this last hypothesis that we favour.

\section{Meticulous and careful constructions}

During astronomical tides, the Molène plateau is affected by very strong tidal currents. Waves are also particularly energetic on the foreshore and subtidal areas of the Molène Archipelago. Despite the high energy of the currents and waves, we note that some of the submerged archaeological remains were still well preserved having survived marine erosion.

One of the biggest and most complex tidal weirs identified on the archipelago is located along the Chimère Channel: Klosenn Malaga' (Fig. 6B). The construction of the deepest part of this structure is attributed to the Early Neolithic, around 7000 years ago. The degree of preservation of the fish trap is exceptional and implies a very meticulous and careful construction. Even if some of the tidal weirs are ruined or damaged, one can only wonder how others have survived so well. The steadying and blocking devices, when these were visible, are extremely simple, with small flat stones for the first, and small elongated pebbles for the second. This apparent simplicity has nevertheless proven to be highly efficient over time, as in some places the combination of standing stones, steadying stones, and blocking pebbles is still perfectly in place. Unfortunately, during the different dives made on these structures, no fresh section has been seen, although these most certainly exist, so it is not yet possible to know how deep the main stones were buried in the substratum and what type of substratum is below the sand. If they are deeply embedded, this may explain their resistance to the currents. Some stones of reasonable size have been seen tilted at $45^{\circ}$, which in turn prevents them from sinking deeply. Based on this observation we propose that the ratio of the upstanding to the buried part is roughly $2 / 3: 1 / 3$.

The issue of repairs to these structures over time should be addressed in order to estimate their duration of use, although no evident signs of repair have been noted to date. If repairs were carried out on the weirs, it must have been during the period of use of the structure as defined in relation to sea level (Fig. 3A), that is, it is not conceivable that a Neolithic tidal weir could be repaired and reused in modern times as it would now be totally under water.

In any case, although the structures show signs of having been built with great care, and their construction must have been time consuming, they did not require any particular technical skills or knowledge. The stones used, whatever their size, were directly available on the 
foreshore (gneiss for Kemenez and Béniguet, granite for Molène), no tool marks were observed - although some may have been hidden by concretions and seaweedimplying no work was done to shape the stones. Nevertheless, it must be acknowledged that the builders intended to make their traps as solid and long-lasting as possible.

These structures, particularly those attributed to the Neolithic, shed a new light on stone constructions of these periods. For instance the two tidal weirs Gwiniman-1 and 2 could reasonably have been built at the same time as the funeral mound excavated in September 2010 at the northern tip of the islet Ledenez Vihan Kemenez (Pailler et al., 2011; Gandois et al., 2013b), just barely $500 \mathrm{~m}$ from the now-submerged structures. Although tidal fish weirs and funerary monuments were built with very different objectives, it is nevertheless informative to compare certain aspects of their construction. Here, for both the funeral mound and the tidal weirs, the size of the stones is identical, but less than 50 have been used for the mound, whereas several hundred were necessary for the weir. In terms of weight (the density of gneiss or granite being roughly the same, around $2.7 \mathrm{t} / \mathrm{m}^{3}$ ), the difference is also striking with the mound representing a few tonnes of stone compared to several hundred tonnes for the weir. The labour, effort and time invested in gathering food to feed everyone involved in constructing a fish weir were much greater than for funerary practices. Moreover the investment made in the quality of the construction is again strikingly different. Since 2008, the northern stone alignment of the mound has had to withstand the ongoing assaults of the sea during exceptional high tides combined with important swell; however the storm of 1 February 2014, which was particularly violent, was enough to destroy one of the two stone alignments within two tides (Gandois et al., 2015a: 59 62) (Fig. 15). On the other hand, many of the weirs, being constantly subject to the swell, still stand firm and erect, thus proving in the most striking manner the care used for their constructions. Admittedly, the funeral mound was not intended to withstand the swell, and indeed almost no serious steadying device was found under the stones. The quality of construction of the weirs, however, cannot be denied, and this despite their original positions on the foreshore, which would automatically have limited the working time available and complicated working conditions as dictated by the rhythm of the tides.

\section{Early megalithic constructions}

One of the most remarkable thing about the deepest, and therefore oldest, tidal weirs is their size: some are still visible for over $400 \mathrm{~m}$, for instance Klosenn Malaga (Fig. 6B) and 300m for Gwiniman-2. Although, precise and meticulous work must still be undertaken on the results of the sonar surveys to estimate the size of the 'fishing surface' available behind each fish trap, there is no doubt that the longer the weir, the bigger the fishing area contained. A simple comparison between the depth and the size of the tidal weirs reveals that the smaller weirs are also the shallowest. Therefore, without getting too involved in the detail of the absolute chronology, it is evident that the size of the structures decreases as sea level rises (Fig. 3A), that is, along with time. Furthermore, the size of the main standing stones constituting the structures decreases with the rise of sea level: the biggest standing stones have been used for the deepest tidal weirs and the smallest for Porz Ar Skao-1 dated to the Medieval period.

Although the builders took advantage of the raw material directly present on the foreshore, nevertheless, for the biggest tidal weirs several hundred stones had to be selected, transported, erected, steadied, and blocked. From a social point of view, the construction of these weirs required a population sufficiently important and organized to build, exploit, and maintain them. The collective efforts of the Neolithic communities to build the megalithic funerary monuments on the Atlantic coasts of Europe has long since been emphasized, so what therefore can be added about the 'alimentary megalithism' of stone tidal weirs? Megalithism is understood here in the strict sense of the displacing and erection of big stones for the purpose of building monumental structures. Funerary structures are well known on the Molène Archipelago (Sparfel et al., 2009; Gandois et al., 2013b), but in terms of mass of stone and therefore of effort provided, these funerary megaliths are small in comparison to the tidal weirs in the Iroise Sea.

Lastly, the oldest tidal weirs could go back as far as the Early Neolithic, maybe even the Late Mesolithic. This early phenomena of 'alimentary megalithism' has been recently discussed for the Atlantic coasts of France (Marchand, 2017), where a few dozen similar structures may have been built during the Mesolithic-Neolithic transition period.

\section{Of tidal weirs and fish...}

The inventory and analysis of these structures are of clear archaeological interest in view of our lack of knowledge and known sites related to fishing techniques used during pre- and protohistoric periods in these regions. Concerning more precisely the Molène Archipelago, several onshore sites have been excavated these past few years, some of them offering extremely numerous fish remains, preserved in shell middens, the limestone in the shells having reduced the acidity of the soil. The settlement site of Beg Ar Loued on the Molène island provided more than 200,000 ichthyologic remains (see inter alia Pailler et al., 2006: 137-141; Pailler et al., 2009: 130-142; Dréano et al., 2013). Five other shell middens have been studied, dating from the Middle Neolithic to the Medieval Period (dating is ongoing for some of the sites): Béniguet-3, island of Béniguet, Le Conquet, Finistère (Dréano et al., 2007: 165-169); Béniguet-104, island of Béniguet, Le Conquet, Finistère (Pailler et al., 2008: 4-34); Ledenez 


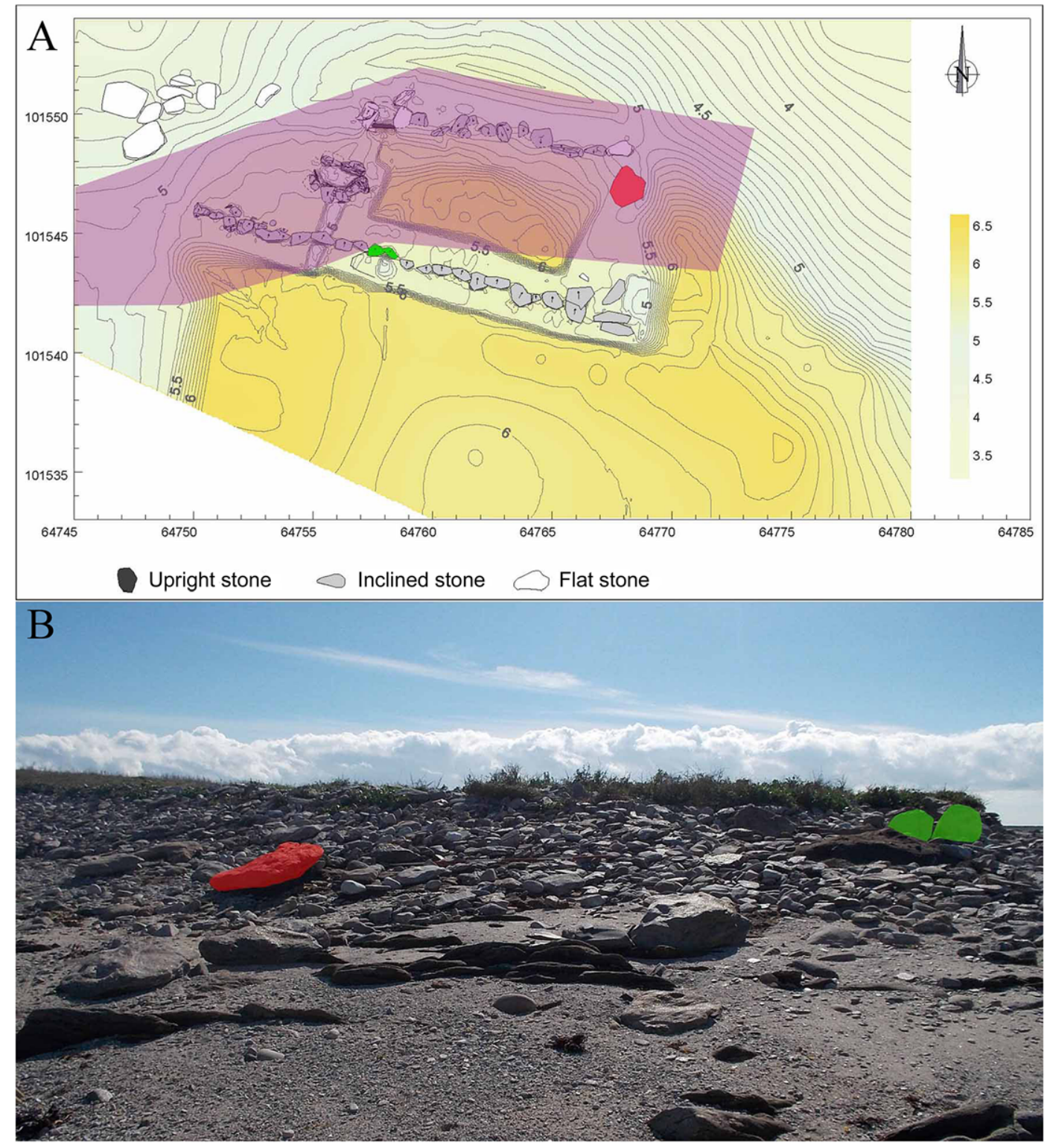

Figure 15. View of the funerary mound on Ledenez Vihan Kemenez: $A$ ) digital terrain model at the end of the excavation, the purple part represents the part wiped out by the storm of 1 February 2014; B) view towards the south in February 2014, the stones coloured in green and red can be found in situ on the plan above (DGPS model J. Goslin and P. Stéphan; Photo: H. Gandois).

Vihan Kemenez, Le Conquet, Finistère (Pailler et al., 2011: 92-95); and sites 22bis and 64, Kemenez, Le Conquet, Finistère (Gandois et al., 2015a, b). We can add four more shell middens on the islands of Litiri and Béniguet, Le Conquet, and Finistère (Gandois et al., 2017b). It is nevertheless very difficult to establish a link between the ichthyofauna and fishing techniques, because none of the sites mentioned above has given any artefact clearly linked to fishing, and this despite systematic sieving. At best, a few notched pebbles that could have been used as net weights have been found in Beg Ar Loued (Dréano et al., 2013). The shell pit of site 22 bis on Kemenez also produced a small granite pebble with a pecked groove around it (unpublished) that could have been used as a weight for a fishing-line, but this remains anecdotal. This appalling lack of fishing gear could hint that the tidal weirs were the main means of fishing in the pre- and protohistoric periods. Several arguments seem to confirm this idea: the estimated size of the fish found in the shell middens, as well as the diversity of the ichthyofauna show non selective fishing was being practised. Moreover, all the fish remains found could have been fished near the shore of the islands, that is from tidal weirs (Dréano et al., 2013). Despite the density of surviving tidal weirs around the Molène Archipelago, the very low occurrence of 
toponyms containing the term gored or 'fish trap', very likely indicates that this fishing technique was since long abandoned.

\section{Conclusion}

The disproportionate number of funerary monuments to domestic structures in the pre- and protohistoric periods on the Molène Archipelago is at first sight surprising. As a result these islands have been called an 'archipelago for the dead' (Scarre, 2011: 156). Continental populations were thought to have sailed there to bury their dead, believing the islands where the sun sets had a psychopomp role, traversing the frontier between the world of the dead and the world of the living (Scarre, 2011: 156-158). The discovery and excavation of domestic structures during episodes of significant shoreline retreat in the winter of 2014 (Gandois et al., 2015a, b, 2017b), have tempered these views. Moreover, the numerous tidal weirs discovered these past few years indicate that the islands of the Iroise Sea were inhabited by local populations. The abundance of funerary monuments is likely a reflection of a high level of preservation compared to the continent as a result of the lack of mechanized agriculture on the islands. They are now seen to reflect the burial practices of a sedentary population.

The dating technique for tidal weirs developed here is, in absence of other means, the most reliable currently available. It seems unlikely that organic remains (wood) will be found within the structures that are suitable for radiocarbon dating. However, other methods look quite promising, for instance Optically Stimulated Luminescence dating has been used on the fish trap of the Petit-Taureau, at ServelLannion, Côtes-d'Armor by Marie-Yvane Daire (pers. comm.) and her team, but still needs further testing. Dating is crucial for this topic: if the oldest structures are indeed Late Mesolithic/Early Neolithic, their exceptional dimensions will bring new insight to the origin of megalithism. A late mesolithic date is in itself unsurprising for tidal weirs, as some in Ireland have been radiocarbon dated to $6100-5700$ cal. BC
(McQuade and O'Donnel, 2007), and others recorded in Zealand, Denmark (Pederson, 1995: 80-82). In contrast, the use of big stones is remarkable, and can be explained by the lack of substantial timber resources. Concerning France, the only mesolithic stone constructions known to date are the burials on the island of Téviec, Saint-Pierre-Quiberon, Morbihan (Péquart et al., 1937). If they belong to the same period, these are much smaller in terms of volume and mass of stones compared to the tidal weirs in the Iroise Sea. If a mesolithic date is confirmed, or even if the deepest tidal weirs were built during the Early Neolithic, they would still be among the oldest monuments of this type in Europe. We are looking at a proto-megalithism, used for food procurement, which predates the funerary tradition by almost half a millennium.

For all these reasons, the protection of these tidal weirs should be a priority; although they have survived for millennia, some are now facing a clear and present danger that could cause their destruction in the near future. Almost all the tidal weirs presented here are in the heart of the seaweed collecting zone, and, if until now the use of the scoubidou - a rotating iron hook attached to a hydraulic arm used to wind and pull up long kelp fronds - did little harm to the structures, the newly licensed 'Norwegian comb', a heavy metallic dredge dragged along the seafloor that can overturn stones of several tonnes, is frighteningly destructive. During a recreational dive, one of us (D.C.), has seen the effect of the dredge on the fish trap at Klosenn Malaga: where the comb passed, the seafloor was levelled, and the structures erased. This threat has been raised with the competent authorities (DRASSM, PNMI) (Gandois et al., 2011, 2013a), but unfortunately insufficient protection has yet to be put in place. The recent georeferenced sonar surveys have provided exact coordinates for each of the known structures, so precise and restricted protection zones would be very easy to define. Moreover, control of these zones could be monitored through the Automatic Identification System terminals that equip the kelp-harvesting boats. Given the scarcity, age, and our limited knowledge of these structures, they are definitely worth saving.

\section{Acknowledgements}

The authors thank those on the very first dives in 2011: Yves Gladu, Fred Lallement, Hugues Priol and Franck Le Ven; and all the divers of the PNMI, especially Yannis Turpin. Many thanks to those living on or visiting the islands for sharing information: Cécile and Robert Masson, Ludovic Calvez and Aurélien Masson, Jean-Pierre Lafont (ONCFS), Audrey Gazet and Nicolas Moreau. The campaigns would not have been possible without the enthusiastic and warm welcome of the Cuisnier family on Kemenez Island. The partnership with the PNMI has been invaluable for recording the submerged structures and sharing bathymetric survey results. Lastly we address a special thanks to Marie-Yvane Daire (CNRS, UMR CReAAH) for her wise advice and encouragement. Part of this work was supported by the French 'Agence Nationale de la Recherche' through the Laboratoire d'Excellence' LabexMER (ANR-10-LABX-19) programme, and co-funded by a grant from the French government through the 'Investissements d'Avenir' programme. It was also supported by the LTSER-France Zones Ateliers 'Brest-Iroise'.

\section{References}

Baltzer, A., Bonnot-Courtois, C., Cassen, S., Fournier, J., Lorin, A., Cagna, R. and Gillier, A., 2010, Reconnaissance des menhirs subtidaux par sonar latéral et bathymétrie fine en Baie de Quiberon, in Proceedings of the 11th National Meeting of Coastal and Civil engineer, Les Sables d'Olonne, 22-25 june 2010, 439-48. Editions Paralia CFL. 
Blaise, E., Suanez, S., Stéphan, P., Fichaut, B., David, L., Cuq, V., Autret, R., Houron, J., Rouan, M., Floc'h, F., Ardhuin, F., Cancouët, R., Davidson, R., Costa, S., and Delacourt, C., 2015, Bilan des tempêtes de l'hiver 2013-2014 sur la dynamique de recul du trait de côte en Bretagne. Géomorphologie: relief, processus, environnement 21.3, 267-294.

Cassen, S., Baltzer, A., Lorin, A., Fournier, J. and Sellier, D., 2011, Submarine Neolithic stone rows near Carnac (Morbihan), France: preliminary results from acoustic and underwater Survey, in J. Benjamin, C. Bonsall, C. Pickard and A. Fisher (eds), $A$ Submerged Prehistory Archeology, 99-110. Oxford.

Connaway, J.M., 2007, Fishweirs: A World Perspective with Emphasis on the Fishweirs of Mississippi. Mississippi Department of Archives and History.

Cordier, C., 2012, Traitement des données Geoswath et EM1000 dans le cadre du projet PNMI. Archive Institutionnelle de l'IFREMER.

Daire, M-Y. and Langouët, L., 2008, Les pêcheries de Bretagne, Archéologie et Histoire des pêcheries d'estran. Coédition Ce.R.A.A-A.M.A.R.A.I, Les Dossiers du Centre Régional d'Archéologie d'Alet.

Daire, M-Y. and Langouët, L., 2010, Les anciens pièges à poissons des côtes de Bretagne, un patrimoine au rythme des marées... Coédition Ce.R.A.A.-A.M.A.R.A.I., Les dossiers du Centre Régional d'Archéologie d'Alet.

Daire, M-Y. and Langouët, L., 2011, Dater les anciennes pêcheries par les niveaux marins. Approche méthodologique et perspectives géoarchéologiques: le Bas Léon, nord Finistère, Bretagne. Norois 220, 69-93.

Donato, V., 2010, Litto3D. Laser Techniques and Applications, in Proceedings of the Ocean and Coastal Observation Sensors and Systems (OCOSS 2010) conference, Sea Tech Week Congress, 21-25 June 2010, 43-48. Brest, France.

Dréano, Y., Gandois, H. and Pailler, Y., 2013, L'exploitation des poissons dans l'archipel de Molène (Finistère, France) du Néolithique récent à l'Âge du Bronze ancien, in M-Y. Daire, C. Dupont, A. Baudry, C. Billard, JM. Large, L. Lespez, E. Normand and C. Scarre (eds), Ancient maritime communities and the relationship between people and environment along the European Atlantic coasts/Anciens peuplements littoraux et relations hommelmilieu sur les côtes de l'Europe atlantique. Proceedings of the HOMER 2011 Conference, Actes du colloque HOMER 2011 (Vannes, 28 septembre-1er octobre 2011), 447-457. British Archaeological Reports International Series 2570, Oxford.

Dréano, Y., Giovannacci, S., Dupont, C., Gruet, Y., Hoguin, R., Ihuel, E., Leroy, A., Marchand, G., Pailler, Y., Sparfel, Y. and Tresset, A., 2007, Le patrimoine archéologique de l'île Béniguet (Le Conquet, Finistère)-Bilan des recherches $2000-2007$. Bulletin de la Société des Sciences Naturelles de l'Ouest de la France, nouvelle série 29.3, 161-172.

Fichaut B. and Suanez S., 2011, Carrying, transport and deposition of cliff-top storm deposits during extreme event: Banneg Island, Brittany. Marine Geology 283, 36-55.

Gandois, H., (ed.) with contributions by Berrio, L., Blaise, E., Dréano, Y., Fontana, L., Ihuel, E., Salanova, L. and Stéphan, P. and the collaboration of Bedault, L., Chambon, P., Cuisnier, D., Hachem, L., Leduc, C., Piliougine, C. and Raffin, A., 2015a, Rapport d'opérations (fouilles archéologiques d'urgence en contexte d'estran) sur les îles de Kemenez, Béniguet et Trielen (Le Conquet, Finistère), opération OA-2463. DRASSM, Marseille.

Gandois, H., (ed.) with contributions by Chambon, P., Dréano, Y., Favrel, Q., Ihuel, E., Maigrot, Y. and Peter, P. and the collaboration of Bedault, L., Hachem, L. and Leduc, C., 2015b, Rapport préliminaire d'opération (fouilles archéologiques d'urgence en contexte d'estran) sur l'île de Kemenez et l'îlot du Ledenez Vraz Kemenez (Le Conquet, Finistère), opération OA2643. DRASSM, Marseille.

Gandois, H., (ed.) with contributions by Mougne, C., Dupont, C., Marcoux, N., Dréano, Y., Favrel, Q., Kerner, J., Gilbert, N., Colleter, R. and Rousseau, L., 2017a, Rapport préliminaire d'opération de fouille sur le Domaine Public Maritime: site 22bis, île de Kemenez (Le Conquet, Finistère), opération OA-2941. DRASSM, Marseille.

Gandois, H., (ed.) with contributions by Mougne, C., Marcoux, N., Favrel, Q., Dupont, C., Gilbert, N. and Berrio, L., 2017b, Rapport préliminaire d'opération de prospections fouille sur le Domaine Public Maritime des îles de Béniguet, Kemenez, Litiri et Trielen (Le Conquet, Finistère), opération OA-2952. DRASSM, Marseille.

Gandois, H., Pailler, Y., Stéphan, P. and Nicolas, C., 2013b, L'érosion marine et ses effets sur les vestiges archéologiques en mer d'Iroise: exemple de l'impact de la tempête de mars 2008 sur l'île Kemenez et ses Ledenez (Le Conquet, Finistère, France), in M-Y. Daire, C. Dupont, A. Baudry, C. Billard, J-M. Large, L. Lespez, E. Normand and C. Scarre (eds), Ancient maritime communities and the relationship between people and environment along the European Atlantic coasts/Anciens peuplements littoraux et relations hommelmilieu sur les côtes de l'Europe atlantique. Proceedings of the HOMER 2011 Conference, Actes du colloque HOMER 2011 (Vannes, 28 septembre-1er octobre 2011), 99-110. British Archaeological Reports International Series 2570, Oxford.

Gandois, H., Stéphan, P., Cuisnier, D., Cuisnier, S. and Masson, A., 2011, Prospections sur les estrans lors des grandes marées de Mars 2011 et en plongée en Avril 2011 sur l'archipel de Molène, in Y. Pailler and H. Gandois (eds), Programme Archéologique Molénais, Rapport 16, Sondage sur un tertre funéraire du Néolithique moyen à la pointe nord du Ledenez Vihan de Kemenez (Le Conquet, Finistère) et sites nouvellement découverts dans l’archipel (îles de Kemenez et Béniguet), 121-140. SRA Bretagne.

Gandois, H. (ed.) and Stéphan, P., with the collaboration of Cuisnier, D., Gladu, Y., Lallement, F. and Priol, H., 2013a, Rapport sur les prospections sous-marines et sur la zone d'estran en mer d'Iroise, opération OA-1746. DRASSM, Marseille.

Goslin, J., Van Vliet Lanoe, B., Spada, G., Bradley, S., Tarasov, L., Neill, S. and Suanez, S., 2015, A new Holocene relative sealevel curve for western Brittany (France): Insights on isostatic dynamics along the Atlantic coasts of north-western Europe. Quaternary Science Reviews 129, 341-365.

Goslin, J., Van Vlie-Lanoë, B., Stéphan, P., Delacourt, C., Fernane, A., Gandouin, E., Hénaff, A., Penaud, A. and Suanez, S., 2013, Holocene relative sea level changes in western Brittany (France) between 8000 and 4000 cal. yr B.P.: reconstitution from basal-peat deposits. Géomorphologie: Relief. Processus. Environnement 4, 425-444.

(C) 2017 The Authors. International Journal of Nautical Archaeology (C) 2017 The Nautical Archaeology Society. 
Iwabuchi, A., 2014, Stone Tidal Weirs, Underwater Cultural Heritage or Not?, in H. van Tilburg et al. (eds), Proceedings of the 2nd Asia-Pacific Regional Conference on Underwater Cultural Heritage, Honolulu, vol. 2, APCONF 2014: $735-746$. Honolulu.

Langouët, L., 2008, Des pêcheries ou écluses sur des cartes du XVIIème au XIXème siècles, in M-Y. Daire and L. Langouët (dir.), Les pêcheries de Bretagne, Archéologie et Histoire des pêcheries d'estran. Centre Régional d'Archéologie d'Alet, Association Manche Atlantique pour la Recherche Archéologique dans les Îles.

Le Gall, B., Authemayou, C., Ehrhold, A., Paquette, J-L., Bussien, D., Chazot, G., Aouizerat, A. and Pastol, Y., 2014, LIDAR offshore structural mapping and $\mathrm{U} / \mathrm{Pb}$ zircon/monazite dating of Variscan strain in the Leon metamorphic domain, NW Brittany. Tectonophysics 630, 236-250.

McQuade, M. and O'Donnel, L., 2007, Late Mesolithic fish traps from the Liffey estuary, Dublin, Ireland. Antiquity 81, 569-584.

Madeg, M., Pondaven, P. and Riou, Y., 2004, An Enezeier, Renabl anoiou lehiou inizi Kornog Goueled Leon: Molenez, Bannog, Balenog, Trielen, Kemenez, Litiri, Benniged, Ar Vein Zu. Emgleo Breiz Ar Skol Vrezoneg, Brest.

Marchand, G., 2017, Aux origines du phénomène mégalithique dans l'Ouest de la France, in L. Manolakakis, N. Schlanger and A. Coudart (eds), European Archaeology, Identities \& Migrations/Archéologie européenne, identités \& migrations, Hommages à Jean-Paul Demoule, 387-408. Leiden, Sidestone Press.

Neill, S.P., Scourse, J.D., and Uehara, K., 2010, Evolution of bed shear stress distribution over the northwest European shelf seas during the last 12,000 years. Ocean Dynamics 60, 1139-1156. http://doi.org/10.1007/s10236-010-0313-3.

Pailler, Y. and Gandois, H. (eds), Assous-Plunian, M., Nicolas, C., Donnart, K., Dupont, C., Dréano, Y., Tresset, A. and Debue, K., 2008, Programme Archéologique Molénais, Rapport 10: prospections dans l'archipel de Molène (Finistère). Service Régional de l'Archéologie de Bretagne, Rennes.

Pailler, Y. and Gandois, H. (eds), with contributions by Dréano, Y., Duigou, L., Josselin, J., Nicolas, C. and Stéphan, P., 2011, Programme Archéologique Molénais (rapport 16), sondage sur un tertre funéraire du Néolithique moyen à la pointe nord du Ledenez Vihan de Kemenez (Le Conquet, Finistère), sites nouvellement découverts dans l'archipel (Kemenez, Béniguet). Service Régional de l'Archéologie de Bretagne, Rennes.

Pailler, Y., Gandois, H. and Tresset, A. (eds) with contributions by Bailon, S., Bourgarit, D., Boury, L., Callou, C., Cariolet, J-M., Carrion, Y., Chambon, P., Darboux, J.R., David, L., Debue, K., Donnart, K., Dréano, Y., Fichaut, B., Goslin, J., Guéret, C., Gonidec, J-P., Le Clézio, L., Le Gall, B., Marcoux, N., Marguerie, D., Mayer, A., Nicolas, C., Pineau, A., Salanova, L., Sellami, F., Staub, A., Stéphan, P., Suanez, S. and Troalen, L., 2009, Programme Archéologique Molénais, rapport 14, Beg ar Loued: un habitat en pierres sèches campaniformel Age du bronze ancien, fouille programmée triannuelle (île Molène; Finistère), 3ème année-2009, Opération 2007-212. Service Régional de l'Archéologie de Bretagne, Rennes.

Pailler, Y., Giovannacci, S., Ihuel, E. and Tresset, A. (eds), with contributions by Bougio, Y., Darboux, J.R., Debue Fravel, K., Dietsch-Sellami, M-F., Donnart, K., Dréano, Y., Dupont, C., Gandois, H., Jean, F., Le Clézio, L., Le Gall, B., Lourdeau, A., Paulet, Y-M., Querné, J., Rousselet, O., Sellami, F. and Troalen, L., 2006, Programme Archéologique Molénais, Rapport 8. Beg ar Loued: un habitat en pierres sèches de la fin du Néolithique / Âge du Bronze ancien, fouille programmée du site de Beg ar Loued (île Molène, Finistère), Opération 2005-230. Service Régional de l'Archéologie de Bretagne, Rennes.

Pailler, Y., Stéphan, P., Gandois, H., Nicolas, C., Sparfel, Y., Tresset, A., Donnart, K., Dréano, Y., Fichaut, B., Suanez, S., Dupont, C., Audouard, L., Marcoux, N., Mougne, C., Salanova, L., Sellami, F. and Dietsch-Sellami, M-F., 2014, Landscape evolution and human settlement in the Iroise Sea (Finistère, Brittany, France) during the Neolithic and Bronze Age. Proceedings of Prehistoric Society 80, 105-139.

Pastol, Y., Le Roux, C. and Louvart, L., 2007, LITTO3D. A Seamless Digital Terrain Model. International Hydrographic Review 8.1, 38-44.

Péquart, M., Péquart, S-J., Boule, M. and Vallois, H-V., 1937, Téviec, station-nécropole mésolithique du Morbihan. Archives de l'Institut de paléonthologie humaine, Fondation Albert Ier, Paris.

Pederson, L., 1995, 7000 years of fishing: stationary fishing structures in the Mesolithic and afterwards, in A. Fischer (ed.), Man and Sea in the Mesolithic, 75-86. Oxbow Books, Oxford.

Roué, D. and Le Goff, J-C., 2008, Barrages à poissons et pêcheries à Santec (Nord-Finistère), in M-Y. Daire and L. Langouët (dir.), Les pêcheries de Bretagne, Archéologie et Histoire des pêcheries d'estran, 97-111. Coédition Ce.R.A.A-A.M.A.R.A.I, Les Dossiers du Centre Régional d'Archéologie d'Alet.

Scarre, C., 2011, Landscapes of Neolithic Brittany. Oxford University Press.

SHOM, 2013, Marine Altimetric References, Cotes du zéro hydrographique et niveaux caractéristiques de la marée, 113. SHOM, Brest. http://data.shom.fr.

Sparfel, Y. and Pailler, Y. (ed.), with contributions by Chaigneau, C., Chauris, L., Fichaut, B., Gouletquer, P., Stéphan, P., Suanez, S. and Tanguy, B., 2009, Les mégalithes de l'arrondissement de Brest, inventaire et essai de synthèse. Institut culturel de BretagneCentre Régional d'Archéologie d'Alet.

Stéphan, P., 2011, Colmatage sédimentaire des marais maritimes et variations relatives du niveau marin au cours des 6000 dernières années en rade de Brest (Finistère). Norois 220, 9-37.

Stéphan, P. and Goslin, J., 2014, Évolution du niveau marin relatif à l'Holocène le long des côtes françaises de l'Atlantique et de la Manche: réactualisation des données par la méthode des 'sea-level index points'. Quaternaire 25, 4, $295-312$.

Stéphan, P., Goslin, J., Pailler, Y., Manceau, R., Suanez, S., Van Vliet-Lanoë, B., Hénaff, A. and Delacourt, C., 2015, Holocene salt-marsh sedimentary infillings and relative sea-level changes in West Brittany (France) from foraminifera-based transfer functions. Boreas 44.1, 153-177.

Stéphan, P. and Laforge, M., 2013, Mise au point sur l'évolution géomorphologique et le devenir des flèches de galets du Loc'h de Landévennec (Bretagne, France). Géomorphologie: Relief. Processus. Environnement 2, 191-208. 
Stéphan, P., Pailler, Y., Tresset, A. and Gandois, H., 2013, Changements paléogéographiques de l'archipel de Molène (Finistère, Bretagne, France): implications sur les peuplements humains du Néolithique à l'Âge du Bronze, in M-Y. Daire, C. Dupont, A. Baudry, C. Billard, J-M. Large, L. Lespez, E. Normand and C. Scarre (eds), Ancient maritime communities and the relationship between people and environment along the European Atlantic coasts/Anciens peuplements littoraux et relations hommelmilieu sur les côtes de l'Europe atlantique. Proceedings of the HOMER 2011 Conference, Actes du colloque HOMER 2011 (Vannes, 28 septembre-1er octobre 2011), 647-660. British Archaeological Reports International Series 2570, Oxford.

Suanez, S., Fichaut, B. and Magne R., 2009, Cliff-top storm deposits on Banneg Island, Brittany, France: Effects of giant waves in the Eastern Atlantic Ocean. Sedimentary Geology 220, 12-28.

Suanez, S., Fichaut, B., Magne, R., Ardhuin, F., Corman, D., Stéphan, P. and Cariolet, J-M., 2011, Changements morphologiques et bilan sédimentaire des formes fuyantes en queue de comète de l'archipel de Molène (Bretagne, France). Géomorphologie: Relief. Environnement. Processus 2, 187-204.

Uehara, K., Scourse, J.D., Horsburgh, K.J., Lambeck, K. and Purcell, A.P., 2006, Tidal evolution of the northwest European shelf seas from the last glacial maximum to the present. Journal of Geophysical Research 111, C09025. 